\title{
Mid-term Impacts of Silvicultural Treatments on Soils and Understory Plant Diversity in Temperate Hardwood Forests of Quebec, Canada.
}

\section{Romain Jaeger ( $\sim$ jaer01@uqo.ca )}

Université du Québec en Outaouais: Universite du Quebec en Outaouais https://orcid.org/0000-00018379-5854

\section{Sylvain Delagrange}

Université du Québec en Outaouais: Universite du Quebec en Outaouais

\section{Isabelle Aubin}

Natural Resources Canada

\section{Gilles Joanisse}

Centre d'enseignement et de recherche en foresterie de Sainte-Foy

\section{Patricia Raymond}

Gouvernement du Québec: Gouvernement du Quebec

\section{David Rivest}

Université du Québec en Outaouais: Universite du Quebec en Outaouais

\section{Research Article}

Keywords: Beta diversity, Biotic homogenization, Forest succession, Scarification, Soil physico-chemical properties

Posted Date: June 29th, 2021

DOl: https://doi.org/10.21203/rs.3.rs-651074/v1

License: (c) (1) This work is licensed under a Creative Commons Attribution 4.0 International License. Read Full License 


\section{Abstract}

Background: Short-term effects of silvicultural treatments on soil properties and understory vegetation in temperate hardwood forests are well documented, but few studies have examined longer term effects of treatment intensity. We hypothesized that short-term effects of silvicultural treatments on understory plant diversity do persist over the medium-term (20 years after treatment); the magnitude of these effects would be proportional to the intensity of canopy and soil disturbance.

Methods: Soil properties ( $\mathrm{pH}$, total $\mathrm{C}$ and $\mathrm{N}$, extractable $\mathrm{P}$, exchangeable bases) and understory community diversity indices were measured in six experimental sites along a longitudinal gradient that covered different climatic and edaphic conditions in the yellow birch-sugar maple bioclimate domain. Reference condition, i.e. control forest with no anthropogenic disturbance for at least 80 years (CON) were compared to twenty years old regeneration treaments representing a gradient of canopy and soil disturbance intensity: single-tree selection cuts (SIN); group-selection cuts (GRP); and group-selection cuts with scarification (GRPS).

Results: Geographic location of sites explained more variation in soil properties and community composition than did treatments. Species richness in both group-selection treatments was higher than that in CON forests. However, understory plant equitability and beta diversity among sites in GRP and GRPS were lower than in SIN and CON forests. More intense treatments (GRP and GRPS) increased the relative occurrence of vegetatively reproducing heliophilic plants, a trait syndrome associated with adaptations to disturbed environments. These treatments also contributed to the medium-term persistence of recalcitrant competitor species (e.g., Rubus idaeus, Prunus pensy/vanica) whereas soil scarification appears to have negative sustained effects on species known to be sensitive to regeneration treatments (e.g. Monotropa uniflora, Dryopteris spinulosa).

Conclusion: Of the treatments studied, single-tree selection cutting appears to be the most appropriate silvicultural treatment for maintaining soil functions and heterogeneous understory plant communities with compositions and structures similar to natural forests, while more intense treatments rather maintain and expand species that are better adapted to a wider range of environmental conditions, including open environments.

\section{Background}

Within temperate forest ecosystems, the diversity of understory plant communities is a key determinant of forest dynamics. These communities play important roles in the occurrence and maintenance of several key ecological processes (e.g., nutrient recycling, regeneration; Gracia et al. 2007; Moisan-De Serres et al. 2018). Yet, these communities exhibit increased environmental sensitivity that could be exacerbated by repeated harvesting pressures that disturb both the soil and forest cover (Roberts and Zhu 2002; Ellum 2009). 
Since the 1990s, researchers have been interested in the relationships between silvicultural treatment intensification (i.e., increased disturbance intensity or frequency; Foley et al. 2005), forest productivity and biodiversity (Gilliam and Roberts 1995; Brockerhoff et al. 2008; Paquette and Messier 2010). Some have suggested that intensification required of forest management practices threatens forest landscapes (e.g., through decreases in structural complexity; Chaudhary et al. 2016) and biodiversity (e.g., changes in species composition, decreases in heterogeneity and functional diversity; Lindenmayer 2012, 2016; Gauthier et al. 2016; Yeboah et al. 2016; Messier et al. 2019). Others have suggested that by maintaining forest harvesting, more services in fact are produced (e.g., wood production) than could be achieved without management (Puettmann et al. 2009; O'Hara 2015).

In temperate hardwood forests, silvicultural treatments can have contrasting effects on biotic and abiotic conditions (Siemion et al. 2011; Duguid and Ashton 2013). Different levels of soil and canopy disturbance intensity, relative to the size of canopy openings and the nature of machinery that is used, can alter plant community composition and soil properties (Roberts 2004). For example, species richness and relative abundance of shade-intolerant species increases with the percentage of canopy openings (Keenan and Kimmins 1993). In contrast, small canopy openings, such as those that are created by natural disturbances, i.e., senescence and death of an individual tree or small group of individuals, tend to maintain the native flora of closed natural environments (Angers et al. 2005; Poznanovic et al. 2013). Large canopy disturbances also provide opportunities for competitive pioneer species to establish and spread over the short-term (Webster and Lorimer 2005), which can interfere with the regeneration of commercially important species (Royo and Carson 2006; Shields and Webster 2007; Powers and Nagel 2009) and locally decrease the occurrence of late-successional species (Paillet et al. 2010; Duguid and Ashton 2013). Also, while emulation of strong soil disturbances that are caused by windthrow in the case of the natural disturbance regime, or following scarification, are implemented to create microsites that favour desired commercial species, e.g., Betula alleghaniensis Britton (yellow birch) (Erdmann 1990), the application of these techniques can also substantially modify soil physico-chemical properties, such as reductions in $\mathrm{C}$ and $\mathrm{N}$ concentrations, soil compaction and decreases in the organic horizon thickness (Siemion et al. 2011; Chaudhary et al. 2016).

Management of North American hardwood forests has evolved towards alternative regeneration processes in order to maintain forests that are resilient to global change and to address problems that are related to biodiversity conservation. These alternative forms of management include partial cuts, which involve lower levels of disturbance that are closer to the natural disturbance regime, i.e., the ecosystem approach (D'Amato et al. 2018). Maintaining a permanent cover and uneven-aged structure allows the natural dynamics of regeneration to be maintained through the accumulation of woody biomass and the development of a complex structure with various tree ages and sizes (Rogers et al. 2018). Forest management that aims to simulate the natural disturbance regime also promotes the presence and maintenance of taxonomic groups that are sensitive to abrupt changes in abiotic conditions (e.g., largeseeded spring geophytes, with poor dispersal; Aubin et al. 2007; Paillet et al. 2010; Duguid and Ashton 2013) in highly diverse vascular plant, moss and lichen communities (Hart and Grissino-Mayer 2009; Hilmers et al. 2018). 
To date, the relationships between understory plant community diversity, soil properties, and the intensity of canopy and soil disturbances remain unclear. In the short-term, hardwood forests that are disturbed by logging tend to have higher species richness than unmanaged forests, but exhibit a lower degree of heterogeneity (Falk et al. 2008; Markgraf et al. 2020). This response is particularly due to the establishment of competitive pioneer species that specialize in openings within communities that are composed primarily of species that are associated with late-successional forests (Archambault et al. 1998; Naaf and Wulf 2007; Moola and Vasseur 2008). During ecological succession, the coexistence of pioneer and late-successional species is generally considered to be transient, i.e., lasting less than 20 years (Moola and Vasseur 2008). However, for a given disturbance, the functional traits of competitive pioneer species and their spatio-temporal capacities to exploit available resources may allow them to remain in the community for longer term and, ultimately, slow down successional trajectories (Roxburgh et al. 2004; Wyatt and Silman 2010). Few studies have investigated this phenomenon in the medium-term ( 20 years after cutting). Thus, it is important to verify whether the intensification of silvicultural treatments contributes both to longer persistence of these competitive species and to the decrease in structural and functional heterogeneity of understory plant communities, or whether it allows a convergence of plant communities towards the attributes of unmanaged forests (Paillet et al. 2010; Duguid and Ashton 2013).

A set of metrics covering taxonomic and functional diversity was selected to capture different dimensions of the response of plant communities to silvicultural treatments (Mayfield et al. 2010). The taxonomic approach can detect the presence of rare species, but its indicators have low analytical power to characterize biodiversity and the effects of disturbance on ecosystem functions (Daly et al. 2018; Willis and Martin 2020). Consequently, substantial variations in understory plant diversity not only remain very difficult to measure, but also difficult to predict along a disturbance intensity gradient on the basis of species richness alone, for example, using meta-analyses (Gilliam and Roberts 1995; Elliott and Knoepp 2005; Paillet et al. 2010; Duguid and Ashton 2013; Nolet et al. 2018). In contrast, the functional approach provides more information on the processes of species responses to biotic and abiotic conditions (Aubin et al. 2007; Lavorel et al. 2007). The study of diversity according to these components thus permits a more detailed understanding to be gained regarding ecological processes and understory dynamics within disturbed systems (Hooper et al. 2005; Cadotte et al. 2011).

The objective of this study was to assess medium-term effects of different regeneration processes on soil properties and on the specific and functional composition of understory plant communities in temperate hardwood forests. We hypothesized that short-term effects of silvicultural treatments on soil properties and understory plant communities persist in the medium-term (i.e., 20 years after treatment); the magnitude of these effects would be proportional to the intensity of both forest canopy and soil disturbance. We measured soil chemical properties ( $\mathrm{pH}$, total $\mathrm{C}$ and $\mathrm{N}$, extractable $\mathrm{P}$, exchangeable bases), together with several indices and metrics of understory plant community diversity, in six experimental sites that had been established primarily in yellow birch-sugar maple (Acer saccharum Marsh.) and yellow birch-balsam fir (Abies balsamea (L.) Mill.) stands in southern Quebec, Canada. We compared a gradient of disturbance intensity treatments: 1) single-tree selection cutting; 2) group-selection cuts; and 
3) group-selection cuts with soil scarification, to reference condition, i.e. control forests with no silvicultural treatment known for $\geq 80$ years.

\section{Materials And Methods}

\section{Study sites and experimental layouts}

Six experimental sites were selected within the Great Lakes-St. Lawrence Forest Region (Rowe 1972) of southern Quebec, Canada, along a longitudinal gradient (Fig. 1) that covered different climatic and edaphic conditions (Table 1). Five sites are located in the yellow birch-sugar maple bioclimatic domain (Saucier et al. 2009), where the latter two species dominated the canopy, with contributions of American beech (Fagus grandifolia Ehrh.), American basswood (Tilia americana L.), and hophornbeam or ironwood (Ostrya virginiana [Mill.] K.Koch). Site six is located in the yellow birch-fir bioclimatic domain.

Consequently, it is dominated by balsam fir and yellow birch, with contributions from trembling aspen (Populus tremuloides Michx.), paper or white birch (Betula papyrifera Marsh.), and white spruce (Picea glauca [Moench] Voss). The creation of small canopy gaps following tree senescence and death is characteristic of the domain's natural disturbance regime, with occasional larger scale disturbances such as windthrows and freezing rain (Runkle 1985). Soils that have developed on the sites are Brunisols and Podzols (Soil Classification Working Group 1998; 7th Approximation: Inceptisols and Spodosols).

Legend: The experimental have a surface area of $1962.5 \mathrm{~m}^{2}$ comprising 52 floristic inventory points and 9 soil sampling points distributed along the four inventory transects. CON: controls; SIN: single-tree selection cuts; GRP: group-selection cuts; GRPS: group-selection cuts with scarification).

The sites were selected with the aim of comparing Control Forest that was not logged for at least 80 years $(\mathrm{CON}, \mathrm{n}=21)$ to three levels of disturbance intensity stemming from the following regeneration treatments. 1) Single-tree Selection Cuts exemplified shelterwood cutting $(S I N, n=13)$, with the goal of removing about $30 \%$ of average basal area. 2) Group-Selection Cuts (GRP, $n=15$ ) resulted in openings ranging in area from $1500 \mathrm{~m}^{2}$ to $2500 \mathrm{~m}^{2}$. 3) Group-Selection Cuts with Scarification (GRPS, $\mathrm{n}=17$ ) created areas that are equivalent to those of GRPs, with the addition of soil disturbance (Table 1). Scarification of the Lac Marcotte and Saint-Michel-des-Saints sites was carried out immediately after GRP using a harrow. At Escuminac, Kipawa and Woburn, scarification was carried out the year following the cut using a mechanical shovel, thereby creating an average 400 pits (ca. $2 \times 3 \mathrm{~m}$ ) per hectare. We have assumed that the two scarification treatments that were considered in this study both generated substantially greater disturbance to the soil and herbaceous layer compared to the unscarified portions. We therefore combined these two scarification approaches into a single treatment for subsequent statistical analyses. Each site consisted of 3-6 randomized complete blocks in which three to four regeneration treatments were compared (Table 1 ). 
Table 1

Environmental, ecological and edaphic characteristics of the study sites that were located in southern Quebec, Canada.

\begin{tabular}{|c|c|c|c|c|c|c|}
\hline Municipality & $\begin{array}{l}\text { ZEC } \\
\text { Kipawa }\end{array}$ & $\begin{array}{l}\text { Lac Gagnon } \\
\text { (Papineau- } \\
\text { Labelle Wildlife } \\
\text { Reserve) }\end{array}$ & $\begin{array}{l}\text { Saint- } \\
\text { Michel- } \\
\text { des- } \\
\text { Saints }\end{array}$ & $\begin{array}{l}\text { Lac Marcotte } \\
\text { (Mastigouche } \\
\text { Wildlife } \\
\text { Reserve) }\end{array}$ & Woburn & Escuminac \\
\hline Latitude & $46^{\circ} 52^{\prime} \mathrm{N}$ & $46^{\circ} 06^{\prime} \mathrm{N}$ & $47^{\circ} 01^{\prime} \mathrm{N}$ & $46^{\circ} 77^{\prime} \mathrm{N}$ & $45^{\circ} 21^{\prime} \mathrm{N}$ & $48^{\circ} 09^{\prime} \mathrm{N}$ \\
\hline Longitude & $78^{\circ} 42^{\prime} \mathrm{W}$ & $75^{\circ} 08^{\prime} \mathrm{W}$ & $74^{\circ} 20^{\prime} \mathrm{W}$ & $73^{\circ} 11^{\prime} \mathrm{W}$ & $70^{\circ} 48^{\prime} \mathrm{W}$ & $66^{\circ} 31^{\prime} \mathrm{W}$ \\
\hline $\begin{array}{l}\text { Mean } \\
\text { annual } \\
\text { temperature } \\
\left({ }^{\circ} \mathrm{C}\right)\end{array}$ & 2.7 & 4.6 & 3.1 & 4.1 & 3.9 & 4.0 \\
\hline $\begin{array}{l}\text { Annual } \\
\text { precipitation } \\
(\mathrm{mm})\end{array}$ & 956 & 1090 & 933 & 1070 & 1367 & 951 \\
\hline $\begin{array}{l}\text { Ecological } \\
\text { type }{ }^{1} \text { (sub- } \\
\text { domain) }\end{array}$ & $\begin{array}{l}\text { YBSM } \\
\text { (west) }\end{array}$ & YBSM (west) & $\begin{array}{l}\text { YBSM } \\
\text { (west) }\end{array}$ & YBSM (east) & $\begin{array}{l}\text { YBSM } \\
\text { (east) }\end{array}$ & YBBF \\
\hline Sand (\%) & 53 & 57 & 53 & 38 & 53 & 21 \\
\hline Clay (\%) & 5 & 33 & 37 & 9 & 38 & 57 \\
\hline $\begin{array}{l}\mathrm{pH}(2: 1 \\
\text { soil:water) }\end{array}$ & $\begin{array}{l}4.5(0.2) \\
2\end{array}$ & $4.9(0.3)$ & $4.5(0.2)$ & $4.7(0.2)$ & $4.7(0.2)$ & $4.7(0.2)$ \\
\hline $\begin{array}{l}\text { Treatments } \\
3\end{array}$ & $\begin{array}{l}\text { CON, } \\
\text { SIN, } \\
\text { GRPS }\end{array}$ & CON, SIN, GRP & $\begin{array}{l}\text { CON, } \\
\text { GRP, } \\
\text { GRPS }\end{array}$ & CON, GRP, GRPS & $\begin{array}{l}\text { CON, } \\
\text { SIN, } \\
\text { GRP, } \\
\text { GRPS }\end{array}$ & $\begin{array}{l}\text { CON, SIN, } \\
\text { GRPS }\end{array}$ \\
\hline $\begin{array}{l}\text { Number of } \\
\text { blocks }\end{array}$ & 3 & 6 & 6 & 3 & 3 & 3 \\
\hline $\begin{array}{l}\text { Year of } \\
\text { cutting }\end{array}$ & 2001 & 2006 & 2000 & 1998 & 1997 & 1999 \\
\hline $\begin{array}{l}\text { Year of } \\
\text { scarification }\end{array}$ & 2002 & - & 2000 & 1998 & 1998 & 2000 \\
\hline \multicolumn{7}{|c|}{${ }^{1}$ Ecological type: YBSM, yellow birch-sugar maple domain, YBBF, yellow birch-fir domain. } \\
\hline \multicolumn{7}{|c|}{${ }^{2}$ The value in parentheses is the standard deviation. } \\
\hline
\end{tabular}

\section{Understory vegetation inventories}


From the end of June to mid-August 2019, herbs, ferns and woody plants up to $2 \mathrm{~m}$ in height (i.e., the understory vegetation) were inventoried in the 66 experimental plots of the study. We did not count spring ephemerals, such as Erythronium americanum (trout lily). All individuals were identified to species using the identification key for vascular plants of the Flore Laurentienne (Marie-Victorin et al. 2002). Given the difficulty of identifying taxa at the vegetative stage in both the genus Carex genus and the family Poaceae, they were respectively grouped under Carex spp. and Poaceae spp. Taxonomic nomenclature was standardized according to the Database of Vascular Plants of Canada (VASCAN; https://data.canadensys.net/vascan).

Each experimental plot (Fig. 1) covered an area of $1962.5 \mathrm{~m}^{2}$ and included 52 inventory points, each with a radius of $15 \mathrm{~cm}$, and separated by $1.5 \mathrm{~m}$. These were systematically distributed along four $25 \mathrm{~m}$ transects following Aubin et al. (2007). We assigned an occurrence value of 1 for each species that was present at an inventory point, with a maximum value of 52 for that same species within an experimental plot. Species present in the plot, yet never encountered at any of the 52 inventory points were scored 0.5 to account for the total species richness of the plot. The total number of recorded occurrences provides an estimate of species abundance. We considered the relative occurrence $(F$, as \%) of a species within a plot by dividing its occurrence value by 52 .

\section{Environmental performance traits}

The environmental performance traits (sensu Violle et al 2007) that were used in the study had been obtained from the TOPIC database (Aubin et al. 2020). These were selected for the analyses because of their links with competitive abilities (biological type) and potential for colonization following disturbance (reproductive mode, shade tolerance; Table 2).

Table 2

Individual environmental performance traits that were included in the analysis.

Trait Description of trait

Biological Qualitative variable: evergreen, deciduous, shrub, bush, sporophyte, monocot, type graminaceae, asterales, other herbaceous plant.

Reproductive Qualitative variable: mainly asexual, mainly sexual, asexual and sexual. mode

Shade tolerance

\section{Soil sampling and laboratory analyses}

We collected a composite sample of the organic $(\mathrm{FH})$ and mineral $(0-20 \mathrm{~cm})$ soil horizons in each experimental plot. Cores ( $8 \mathrm{~cm}$ dia.) were taken at nine sampling points and bulked for each of the plot (Fig. 1). Organic horizon $(\mathrm{FH})$ thickness $(\mathrm{cm})$ was also measured the nine sampling points. Samples were air-dried and sieved to pass a $2 \mathrm{~mm}$ mesh. Bulk pH was measured using a soil:distilled water ratio 
of 1:2 for mineral soil and 1:10 for organic soil (Hendershot et al. 2008). Total nitrogen (N) and carbon (C) concentrations were measured by high-temperature combustion $\left(1450{ }^{\circ} \mathrm{C}\right)$ followed respectively by infrared detection (C) and by thermal conductivity (N) on a TruMac CNS analyzer (LECO, St. Joseph, MI, USA). Phosphorus $(P)$ concentrations were determined colorimetrically (as molybdate blue) on Mehlich III soil extracts (Zidia and Tran 2008) with a flow-injection analyzer (Lachat Instruments, Milwaukee, WI, USA). Exchangeable base ( $\mathrm{Ca}, \mathrm{Mg}, \mathrm{K}, \mathrm{Al})$ concentrations were measured on $\mathrm{BaCl}_{2}(0.1 \mathrm{M})$ soil extracts by atomic absorption spectrophotometry (Varian 220 FS, Agilent Technologies, Palo Alto, CA, USA) (Tran and Simard 2008).

\section{Data analyses}

\section{Soil properties response to treatment}

The effects of silvicultural treatments on each soil property were measured using random-effects generalised linear mixed models ( $\mathrm{glmm}$ ), where sites and blocks that were nested within sites were considered as random effects and silvicultural treatments were treated as fixed effects.

PERMANOVA was also used to assess the variance partitioning of the set of soil properties and tests of their multivariate means among treatments were determined by permutational multivariate analysis of variance (PERMANOVA, Anderson 2017). PERMANOVA (with 999 permutations) tested the effects of silvicultural treatments, sites and their interaction, while constraining permutations within blocks to reproduce random effects.

\section{Relationships between soil properties and plant communities}

Relationships between soil properties and plant community composition and understory species distributions were analyzed using redundancy analysis (dbRDA) that employed Sorensen's index for distance matrix creation (Peres-Neto et al. 2006; Legendre et al. 2009). For this purpose, species that were present in less than $10 \%$ of the plots were excluded, given that rare species provides only limited information regarding habitat preferences and factors influencing co-occurrence between species (Azeria et al. 2012).

\section{Taxonomic response to treatment}

To assess the effects of the different treatments on the understory plant community, we first tested the response of potentially sensitive and potentially recalcitrant species. Among the species in present in our dataset, eight were identified in the literature as being potentially sensitive to soil and canopy disturbance in temperate forests ecosystems: Dryopteris carthusiana (Vill.) H.P. Fuchs (= D. spinulosa [O.F. Muell.] O. Kuntze), Athyrium filix-femina (L.) Roth, Lycopodium spp., Oxalis acetosella ssp. montana (Raf.) Hultén ex Löve, Coptis trifolia Salisb., Monotropa uniflora L., Circaea alpina L., and Cypripedium acaule Aiton (Haeussler et al. 2002; Moola and Vasseur 2004; Flinn 2007). Other species that are known to be sensitive, such as spring geophytes (e.g., Trillium spp., Streptopus lanceolatus (Aiton) Reveal [= $S$. 
roseus Michx.]; Aubin et al. 2007) and orchids (e.g., Goodyera spp.; Turcotte 2008), had too low relative occurrence to be considered in the analysis. Six other species have been identified in the literature as potentially recalcitrant and competitive with commercial woody and late-successional species in eastern Canada (Jobidon 1995; Bell et al. 2011): Acer spicatum L., Corylus cornuta Marshall, Populus tremuloides Michaux, Prunus pensy/vanica L.f., Pteridium aquilinum (L.) Kuhn, and Rubus idaeus L. We tested the differences in relative occurrence between different silvicultural treatments for potentially susceptible and potentially recalcitrant species using one-way ANOVA with permutations $(n=999)$ (Borcard et al. 2011; Anderson 2017). Post hoc multiple comparisons with $t$-tests were performed to separate the treatments. When a significant difference was observed, Bonferroni correction was applied to the $P$-value.

Several univariate measures of alpha diversity were calculated to account for the distributions and patterns of species within understory plant communities. 1) Species richness $(S)$ was measured as the number of species that were present in each plot. 2) The Shannon index or information measure $(H)$ combined species richness $(S)$ and equitability $(E)$ using the geometric mean of proportional abundances of $i$ species $\left(p_{i}\right)$ in the respective communities, which was calculated as: $H^{\prime}=-\sum_{i}{ }_{i} p_{i} \ln p_{i}$ (Shannon 1948). 3) The "effective number" of species (i.e., true diversity) was calculated from the Shannon entropy exponent formula: ${ }^{1} D=\mathrm{e}^{\left(H^{\prime}\right)}$ (Jost 2006). 4) The equitability index $(E)$ was calculated according to the formula: $E={ }^{1} D / S$ (Tuomisto 2010). Effects of silvicultural treatments on alpha diversity indices were analyzed using random-effects generalized linear mixed models ( $\mathrm{glmm}$ ) that were equivalent to those used for soil properties.

\section{Functional response to treatment}

In order to compare the functional diversity between different silvicultural treatments, we first calculated the functional dispersion index (Fdis, Laliberté and Legendre 2010). We also calculated the functional diversity of each individual trait using the Rao index (Rao 1982), to compare the variation of species traits composition within the communities. Finally, we determined the community-weighted means (CWM) for three environmental performance traits, namely 1 ) biological type, 2) reproductive mode, and 3) shade tolerance, to compare functional redundancy between silvicultural treatments.

\section{Beta diversity}

Beta diversity was measured to quantify the extent of heterogeneity between plots within the same silvicultural treatment, between plots of different treatments, and between sites (Appendix A). Within a treatment, beta diversity $\left(B_{\text {within_Treat }}\right)$ was calculated as the alpha diversity $\left({ }^{1} D\right)$ that was measured at the plot level, divided by the average ${ }^{1} D$, which was calculated for each of the three plots in the treatment (Anderson et al. 2011; Royer-Tardif et al. 2018). To compare beta diversity between regeneration treatments, we considered $B_{\text {between_Treat }}$ to be the multivariate dispersion of vegetation composition (Anderson et al. 2011) by calculating the average distance to the centroid for all plots within a treatment. To compare beta diversity between sites for each treatment, we considered $\mathrm{B}_{\text {between_Site }}$ as the multivariate dispersion of vegetation composition by calculating the average distance between centroids 
of sites for the same treatment. Both distance calculations were based on the Euclidean distance matrix corresponding to distance to centroid (dcen) (Anderson et al. 2011).

\section{Species composition patterns}

We assessed compositional differences between regeneration treatments using PERMANOVA (based on 999 permutations; Anderson 2017) based on distance matrices that were calculated from Hellinger distances. PERMANOVA tested for differences in species assemblages among silvicultural treatments and among sites, together with their interaction (Treatments $x$ Sites). When significant differences were detected for the interaction and main effects, we performed multiple comparison tests; $P$-values were adjusted using the Holm-Bonferroni sequential method. A significant result that is obtained by PERMANOVA may originate from mean differences in species assemblages between the treatments, may indicate differences in variation within treatments (i.e., heterogeneity in multivariate scatter within groups), or may be a combination of both. To provide the appropriate interpretation of significant results, we used the function PERMDISP to test the homogeneity of the multivariate spread. PERMDISP is a permutation-based multivariate extension of Levene's test of homogeneity of variance (Anderson 2017). When these tests detected significant differences, we used the function TukeyHSD(0) to perform pairwise means comparisons of the different regeneration treatments.

We used a measure of multivariate functional dispersion

(FDis; Lalibert é and Legendre 2010) to compare trait

diversity between baseline and future conditions using data

on all traits simultaneously. FDis calculates the average

distance of individual species to their group centroid in

multivariate trait space that has been defi ned by an appropri-

ate distance measure. Tighter clustering of species in multi-

variate trait space corresponds to lower functional diversity

and thus lower FDis values. Although a range of functional

diversity indices exist we chose FDis because, unlike other

techniques, it is largely unaff ected by species richness

(sample size).

We used a measure of multivariate functional dispersion 
(FDis; Lalibert é and Legendre 2010) to compare trait

diversity between baseline and future conditions using data

on all traits simultaneously. FDis calculates the average

distance of individual species to their group centroid in

multivariate trait space that has been defi ned by an appropri-

ate distance measure. Tighter clustering of species in multi-

variate trait space corresponds to lower functional diversity

and thus lower FDis values. Although a range of functional

diversity indices exist we chose FDis because, unlike other

techniques, it is largely unaff ected by species richness

(sample size

The random effects mixed models were performed with the function $\mathrm{g} / \mathrm{mm} T M B($ ) in the $\mathrm{g} / \mathrm{mm} T M B$ package (Brooks et al. 2017). Tukey post hoc tests for generalized linear random effects models were performed with the functions TukeyHSD() or glht) from the multcomp package (Hothorn et al. 2008). Hellinger transformations were performed with the function decostand(); multivariate dispersion analyses were performed with betadisper(); and centroid positions were tested with adonis20. All of these functions are from the vegan package (Oksanen et al. 2017). Beta diversity partitioning was performed with the function beta.pair() from the betapart package (Baselga 2010, 2012). All statistical analyses were performed in $\mathrm{R}$ ( $\mathrm{R}$ version 3.5.2; $\mathrm{R}$ Core Team 2017).

\section{Results}

\section{Effects of silvicultural treatments on soil properties}

According to the multivariate variation-partitioning test (PERMANOVA), site location explained a significant portion of the variation in soil properties $\left(R^{2}=0.36, P<0.001\right)$. Treatments alone had a small but significant effect on variation in these properties $\left(R^{2}=0.05, P=0.039\right)$ (Table 3). Multiple comparison tests showed no significant differences in soil properties between each pair of silvicultural treatments (Table 4). 
Table 3

Multivariate variation partitioning (PERMANOVA) of soil properties, species assemblage and biological type assemblage across regeneration treatments, sites and their interaction.

\begin{tabular}{|c|c|c|c|c|c|c|}
\hline \multirow[b]{2}{*}{ Source } & \multicolumn{2}{|c|}{ Soil properties } & \multicolumn{2}{|c|}{ Species assemblage } & \multicolumn{2}{|c|}{ Biological type assemblage } \\
\hline & $R^{2}$ & $P$ & $R^{2}$ & $P$ & $R^{2}$ & $P$ \\
\hline Treatments & 0.05 & 0.039 & 0.07 & $<0.001$ & 0.10 & $<0.001$ \\
\hline Sites & 0.36 & $<0.001$ & 0.44 & $<0.001$ & 0.35 & $<0.001$ \\
\hline Treatments * Sites & 0.08 & 0.848 & 0.10 & 0.046 & 0.13 & 0.050 \\
\hline Error & 0.50 & & 0.39 & & 0.42 & \\
\hline
\end{tabular}

Table 4

Multiple comparisons (Tukey HSD tests) among regeneration treatments, according to variation in soil properties, species assemblage and biological types.

\begin{tabular}{|lllllll|}
\hline & \multicolumn{2}{l}{ Soil properties } & \multicolumn{2}{c}{ Species assemblage } & \multicolumn{2}{l|}{ Biological type assemblage } \\
\hline Pairs & $P$ & $P$ adjusted & $P$ & $P$ adjusted & $P$ & $P$ adjusted \\
\hline CON vs SIN & 0.070 & 0.420 & 0.442 & 1.000 & 0.212 & 1.000 \\
\hline CON vs GRP & 0.584 & 1.000 & 0.133 & 0.798 & 0.030 & 0.180 \\
\hline CON vs GRPS & 0.588 & 1.000 & 0.008 & 0.048 & 0.004 & 0.024 \\
\hline SIN vs GRP & 0.068 & 0.408 & 0.261 & 1.000 & 0.156 & 0.936 \\
\hline SIN vs GRPS & 0.212 & 1.000 & 0.012 & 0.072 & 0.018 & 0.108 \\
\hline GRP vs GRPS & 0.951 & 1.000 & 0.164 & 0.984 & 0.295 & 1.000 \\
\hline $\begin{array}{l}\text { CON: controls; SIN: single-tree selection cut; GRP: group-selection cut; GRPS: group-selection cut with } \\
\text { scarification. }\end{array}$
\end{tabular}

Univariate analyses of the effect of treatments on each of the soil properties revealed significant differences between treatments for $\mathrm{FH}$ horizon thickness, $\mathrm{C} / \mathrm{N}$ ratio and $\mathrm{K}$ content in the organic horizon and $\mathrm{P}$ content in the mineral horizon (Table 5). FH-horizon thickness in CON was significantly higher (almost two-fold) than in the GRPS. C/N ratio of the organic horizon in the control stands were higher than in the GRPS. In the mineral horizon, P content of the GRPs was three times higher than in the CON. 
Table 5

Soil properties of the organic and mineral horizons, as a function of regeneration treatment.

\begin{tabular}{|c|c|c|c|c|c|}
\hline & Property & Control & $\begin{array}{l}\text { Single-Tree } \\
\text { Selection }\end{array}$ & $\begin{array}{l}\text { Group- } \\
\text { Selection Cut }\end{array}$ & $\begin{array}{l}\text { Group-Selection Cut with } \\
\text { scarification }\end{array}$ \\
\hline \multirow[t]{10}{*}{ Organic } & $\begin{array}{l}\text { FH } \\
\text { thickness } \\
(\mathrm{cm})\end{array}$ & $9.0(7.5) \mathbf{a}$ & $7.4(5.4) a b$ & $6.6(4.7) a b$ & $4.9(3.8) b$ \\
\hline & $\mathrm{pH}$ & $4.6(0.6)$ & $4.5(0.5)$ & $4.8(0.4)$ & $4.7(0.4)$ \\
\hline & $\mathrm{C}(\%)$ & $\begin{array}{l}34.9 \\
(14.6)\end{array}$ & $30.8(11.5)$ & $32.0(11.6)$ & $28.5(9.7)$ \\
\hline & N (\%) & $1.7(0.7)$ & $1.6(0.5)$ & $1.8(0.6)$ & $1.6(0.5)$ \\
\hline & $\mathrm{C} / \mathrm{N}$ & $\begin{array}{l}19.8(4.1) \\
\text { a }\end{array}$ & 19.4 (3.9) ab & 17.6 (1.7) ab & $17.7(3.8) \mathbf{b}$ \\
\hline & $P\left(m g \cdot k^{-1}\right)$ & $\begin{array}{l}33.6 \\
(27.0)\end{array}$ & $26.9(21.7)$ & $27.1(17.7)$ & $30.0(22.6)$ \\
\hline & $\mathrm{K}\left(\mathrm{mg} \cdot \mathrm{kg}^{-1}\right)$ & $\begin{array}{l}325.3 \\
(261.1)\end{array}$ & 217.5 (271.4) & $244.4(146.3)$ & $257.0(144.0)$ \\
\hline & $\begin{array}{l}\mathrm{Ca}\left(\mathrm{mg} \cdot \mathrm{kg}^{-}\right. \\
\left.{ }^{1}\right)\end{array}$ & $\begin{array}{l}2008.1 \\
(1362.3)\end{array}$ & $\begin{array}{l}2323.1 \\
(1622.3)\end{array}$ & $\begin{array}{l}2176.8 \\
(1434.9)\end{array}$ & $2159.9(1317.0)$ \\
\hline & $\begin{array}{l}\mathrm{Mg}\left(\mathrm{mg} \cdot \mathrm{kg}^{-}\right. \\
\left.{ }^{-}\right)\end{array}$ & $\begin{array}{l}222.8 \\
(134.4)\end{array}$ & $251.9(79.9)$ & $284.0(237.3)$ & $231.1(140.9)$ \\
\hline & $\begin{array}{l}\mathrm{Al}\left(\mathrm{mg} \cdot \mathrm{kg}^{-}\right. \\
\left.{ }^{1}\right)\end{array}$ & $\begin{array}{l}1007.0 \\
(856.7)\end{array}$ & $977.1(608.0)$ & $920.9(626.0)$ & 1169.6 (605.5) \\
\hline \multirow[t]{8}{*}{ Mineral } & $\mathrm{pH}$ & $4.6(0.2)$ & $4.8(0.3)$ & $4.6(0.2)$ & $4.6(0.2)$ \\
\hline & C (\%) & $4.9(2.1)$ & $3.3(1.2)$ & $5.0(1.7)$ & $4.5(2.3)$ \\
\hline & N (\%) & $\begin{array}{l}0.30 \\
(0.15)\end{array}$ & $0.21(0.08)$ & $0.30(0.10)$ & $0.28(0.15)$ \\
\hline & $\mathrm{C} / \mathrm{N}$ & $16.8(4.4)$ & $16.8(4.7)$ & $16.6(2.3)$ & $16.7(5.0)$ \\
\hline & $P\left(\mathrm{mg} \cdot \mathrm{kg}^{-1}\right)$ & $5.3(3.4) b$ & $8.6(13.4) a b$ & $15.6(19.2) \mathbf{a}$ & 13.8 (19.4) ab \\
\hline & $\mathrm{K}\left(\mathrm{mg} \cdot \mathrm{kg}^{-1}\right)$ & $\begin{array}{l}46.0 \\
(18.8)\end{array}$ & $49.0(20.2)$ & $41.2(19.5)$ & $39.2(15.1)$ \\
\hline & $\begin{array}{l}\mathrm{Ca}\left(\mathrm{mg} \cdot \mathrm{kg}^{-}\right. \\
\left.{ }^{-}\right)\end{array}$ & $\begin{array}{l}159.5 \\
(165.2)\end{array}$ & $274.1(248.3)$ & $213.0(170.4)$ & $174.1(212.3)$ \\
\hline & $\begin{array}{l}\mathrm{Mg}\left(\mathrm{mg} \cdot \mathrm{kg}^{-}\right. \\
\left.{ }^{-}\right)\end{array}$ & $\begin{array}{l}22.3 \\
(16.6)\end{array}$ & $31.2(17.7)$ & $25.8(27.5)$ & $22.3(26.5)$ \\
\hline
\end{tabular}




\begin{tabular}{|lllll|}
\hline Property & Control & $\begin{array}{l}\text { Single-Tree } \\
\text { Selection }\end{array}$ & $\begin{array}{l}\text { Group- } \\
\text { Selection Cut }\end{array}$ & $\begin{array}{l}\text { Group-Selection Cut with } \\
\text { scarification }\end{array}$ \\
\hline Al (mg.kg- & 1902.2 & 1600.0 & 1951.7 & $1925.0(329.4)$ \\
1 ( $)$ & $(423.0)$ & $(397.5)$ & $(476.8)$ & \\
\hline
\end{tabular}

Values in parentheses are standard deviations of the means. Within rows, mean values followed by the same boldface letter do not differ significantly at $P=0.05$ (Tukey tests).

\section{Relationship between soil properties and plant communities}

Redundancy analysis showed that soil properties were significantly associated with the composition and distribution of understorey plant communities $(P<0.001$; Fig. 2$)$. The set of soil properties that we measured explained $36 \%$ of variation in the specific assemblage of understory plant communities $\left(R^{2}{ }_{a d j}\right.$ $=0.359, P<0.001)$.

Soil properties alone explained $30 \%$ of the variation in the assemblage of biological types $\left(R^{2}{ }_{a d j}=0.304\right.$, $P<0.001)$. RDA ordination and Pearson correlation test show the positive relationships between the presence of conifers and increasing $\mathrm{C} / \mathrm{N}$ ratio of the organic horizon (Pearson $r=0.60, P<0.001$ ), and decreasing soil $\mathrm{pH}$ in the organic $(r=0.46, P<0.001)$ and mineral $(r=0.33, P<0.001)$ horizons.

Legend: Sample treatments are indicated by symbols (CON: controls; SIN: single-tree selection cut; GRP: group-selection cut; GRPS: group-selection cut with scarification), explanatory variables by arrows. Percentage variance explained along each axis corresponds to $R^{2}$.

\section{Effects of silvicultural treatments on the alpha diversity of plant communities}

A total of 149 species were identified in the floristic surveys. We counted an average 30 species in the CON plots, 31 species in SIN plots, 34 species in GRP plots, and 34 species in the GRPS plots. Species richness in GRPs and GRPSs was higher than in CON plots ( $P=0.005$, Fig. 3$)$. Equitability (E) in CON and SIN was higher than in GRPS $(P<0.001)$. True diversity $\left({ }^{1} D\right)$ did not differ among regeneration treatments.

Legend: CON: controls; SIN: single-tree selection cut; GRP: group-selection cut; GRPS: group-selection cut with scarification. Means with different letters significantly differ following pairwise Tukey's tests $(P<$ 0.05). Box-and-whisker plots in each panel display 25th and 75th percentiles (the inter-quartile range from the lower and upper edges of the box), the horizontal lines within boxes indicate the 50th percentiles (medians), and bullets within boxes indicate means; whiskers below and above boxes indicate 10th and 90th percentiles, respectively, beyond which dots indicate outliers (values > 1.5 x IQR).

\section{Effects of silvicultural treatments on taxonomic and functional metrics}


Increasing the intensity of silvicultural treatments significantly affected species richness $(S)$ and relative occurrence $(F)$ of functional categories that were related to biological type, shade tolerance and reproductive mode (Table 6). GRPS increased species richness and relative occurrence, i.e., functional redundancy, of shrubs compared to the other treatments $(P<0.05)$. The relative occurrence of grasses in GRPs and GRPSs was higher than in CON and SIN. Species richness of exclusively vegetatively reproducing and shade-intolerant species in GRPs and GRPSs was higher than in CONs and SINs.

Richness of species with both modes of reproduction (i.e., sexual and vegetative reproduction) and the relative occurrence of shade-intolerant species in GRPs was higher than in SINs. We did not observe any differences among treatments in terms of overall functional diversity (Fdis) (Fig. 3) or functional diversity for each environmental performance trait (Rao index) (Table 6). 
Table 6

Functional diversity (Rao index), mean species richness $(S)$ and mean relative occurrence $(F)$ of environmental performance traits as a function of regeneration treatments.

\begin{tabular}{|c|c|c|c|c|c|}
\hline Biological type & Index & CON & SIN & GRP & GRPS \\
\hline Functional diversity & Rao & 0.40 & 0.41 & 0.41 & 0.42 \\
\hline \multirow[t]{2}{*}{ Evergreen } & $S$ & $1.7(1.0)$ & $1.5(1.1)$ & $1.4(0.9)$ & $1.3(1.3)$ \\
\hline & $F$ & $0.34(0.25)$ & $0.31(0.22)$ & $0.28(0.30)$ & $0.27(0.32)$ \\
\hline \multirow[t]{2}{*}{ Deciduous } & $S$ & $3.2(0.8)$ & $3.2(0.9)$ & $3.8(0.9)$ & $3.5(1.3)$ \\
\hline & $F$ & $0.46(0.33)$ & $0.46(0.45)$ & $0.54(0.33)$ & $0.50(0.33)$ \\
\hline \multirow[t]{2}{*}{ Shrubs } & $S$ & $5.2(1.7)$ & $4.3(1.4)$ & $5.7(1.9)$ & $6.0(1.9)$ \\
\hline & $F$ & $0.43(0.27)$ & $0.36(0.25)$ & $0.48(0.29)$ & $0.50(0.28)$ \\
\hline \multirow[t]{2}{*}{ Bushes } & $S$ & $1.3(0.9) \mathrm{b}$ & $1.8(0.9) \mathrm{b}$ & $1.7(1.0) \mathrm{b}$ & $2.1(0.9) a$ \\
\hline & $F$ & $0.33(0.23) \mathrm{b}$ & $0.44(0.29) \mathrm{b}$ & $0.43(0, .5) b$ & $0.53(0.28) a$ \\
\hline \multirow[t]{2}{*}{ Asterales } & $S$ & $1.3(0.9)$ & $1.1(1.1)$ & $1.6(1.1)$ & $1.1(0.8)$ \\
\hline & $F$ & $0.32(0.25)$ & $0.27(0.18)$ & $0.40(0.26)$ & $0.28(0.22)$ \\
\hline \multirow[t]{2}{*}{ Graminaceae } & $S$ & $0.9(0.8) b$ & $0.8(0.8) b$ & $1.3(0.6) b$ & $1.6(0.6) \mathrm{a}$ \\
\hline & $F$ & $0.45(0.24) \mathrm{b}$ & $0.42(0.16) b$ & $0.63(0.42) a$ & $0.79(0.12) a$ \\
\hline \multirow[t]{2}{*}{ Monocots } & $S$ & $4.5(1.6)$ & $4.2(1.6)$ & $4.3(1.7)$ & $4.9(1.6)$ \\
\hline & $F$ & $0.50(0.27)$ & $0.54(0.26)$ & $0.48(0.26)$ & $0.55(0.34)$ \\
\hline \multirow[t]{2}{*}{ Sporophytes } & $S$ & $4.1(1.6)$ & $3.4(1.5)$ & $4.5(1.6)$ & $4.9(1.6)$ \\
\hline & $F$ & $0.37(0.28)$ & $0.32(0.26)$ & $0.41(0.27)$ & $0.45(0.27)$ \\
\hline \multirow[t]{2}{*}{ Other flowering plants } & $S$ & $5.5(2.9)$ & $6.6(2.1)$ & $6.2(2.0)$ & $6.3(1.9)$ \\
\hline & $F$ & $0.26(0.25)$ & $0.32(0.25)$ & $0.30(0.25)$ & $0.30(0.28)$ \\
\hline \multicolumn{6}{|l|}{ Reproductive mode } \\
\hline Functional diversity & Rao & 0.33 & 0.34 & 0.34 & 0.33 \\
\hline \multirow[t]{2}{*}{ Vegetative } & $S$ & $14.3(4.1) \mathrm{b}$ & $15.3(2.9) \mathrm{b}$ & $15.4(3.2) \mathrm{b}$ & $16.6(2.0) \mathrm{a}$ \\
\hline & $F$ & $0.36(0.27)$ & $0.38(0.28)$ & $0.39(0.29)$ & $0.41(0.33)$ \\
\hline \multirow[t]{2}{*}{ Sexual \& vegetative } & $S$ & $10.0(2.2) a b$ & $9.3(2.4) \mathrm{b}$ & $11.8(2.6) a$ & $12.7(3.5) \mathrm{a}$ \\
\hline & $F$ & $0.41(0.28)$ & $0.38(0.29)$ & $0.47(0.26)$ & $0.48(0.25)$ \\
\hline Sexual & $S$ & $2.5(0.7)$ & $2.2(1.3)$ & $2.6(1.0)$ & $2.7(1.1)$ \\
\hline
\end{tabular}




\begin{tabular}{|c|c|c|c|c|c|}
\hline Biological type & Index & CON & SIN & GRP & GRPS \\
\hline & $F$ & $0.31(0.18)$ & $0.27(0.15)$ & $0.33(0.25)$ & $0.32(0.29)$ \\
\hline \multicolumn{6}{|l|}{ Shade tolerance } \\
\hline Functional diversity & Rao & 0.30 & 0.28 & 0.32 & 0.32 \\
\hline \multirow[t]{2}{*}{ Shade-intolerant } & $S$ & $1.0(1.3) \mathrm{b}$ & $0.6(0.9) \mathrm{b}$ & $2.0(1.1) a$ & $2.5(1.3) a$ \\
\hline & $F$ & $0.15(0.09) a b$ & $0.09(0.09) b$ & $0.29(0.18) a b$ & $0.35(0.20) a$ \\
\hline \multirow[t]{2}{*}{ Intermediate tolerance } & $S$ & $6.9(1.9)$ & $6.9(2.6)$ & $7.5(2.2)$ & $8.1(2.0)$ \\
\hline & $F$ & $0.34(0.25)$ & $0.34(0.26)$ & $0.37(0.27)$ & $0.41(0.27)$ \\
\hline \multirow[t]{2}{*}{ Shade-tolerant } & $S$ & $19.8(5.3)$ & $20.2(4.6)$ & $21.1(4.9)$ & $21.2(3.1)$ \\
\hline & $F$ & $0.41(0.27)$ & $0.42(0.27)$ & $0.44(0.29)$ & $0.44(0.32)$ \\
\hline
\end{tabular}

Values in parentheses are standard deviations of the means. With rows, means followed by the same letter do not differ significantly at $a=0.05$ according to pairwise Tukey's tests. CON: control; SIN: singletree selection cut; GRP: group-selection cut; GRPS: group-selection cut with scarification.

\section{Effects of silvicultural treatments on sensitive vs competitive species}

Intensification of silvicultural treatments resulted in a significant decrease in the relative occurrences of the sensitive species toothed wood fern (Dryopteris spinulosa; $P=0.0154$ ) and ghost pipe (Monotropa uniflora; $P=0.0016)$, together with a marginally significant decrease for northern wood sorrel (Oxalis acetosella ssp. montana; $P=0.085$ ) in GRPS compared to the other silvicultural treatments (Table 7).

Of the six potentially recalcitrant species, intensified disturbances of the canopy and soil had a significant effect on the relative occurrence of pin cherry (Prunus pensylvanica) and raspberry (Rubus idaeus). These two species occurred more frequently in the GRP and GRPS treatments compared to SIN and CON (Table 7). 
Table 7

Taxon-specific responses of potentially sensitive and potentially recalcitrant species to regeneration treatments.

\begin{tabular}{|c|c|c|c|c|c|}
\hline & \multicolumn{4}{|c|}{ Relative occurrence } & \multirow{2}{*}{$\begin{array}{l}\text { ANOVA } \\
p \text {-value }\end{array}$} \\
\hline & CON & SIN & GRP & GRPS & \\
\hline \multicolumn{6}{|l|}{ Sensitive } \\
\hline Athyrium filix-femina & 1.12 & 0.55 & 1.11 & 1.27 & 0.7947 \\
\hline Circeae alpina & 0.37 & 0.23 & 0.26 & 0.06 & 0.7173 \\
\hline Coptis trifolia & 4.96 & 6.52 & 3.69 & 2.65 & 0.5869 \\
\hline Cypripedium acaule & 0.64 & 0.70 & 0.59 & 0.18 & 0.6244 \\
\hline Dryopteris spinulosa & 31.46 & 27.94 & 26.28 & 11.03 & 0.0154 \\
\hline Lycopodium spp. & 1.97 & 1.20 & 1.66 & 1.09 & 0.8245 \\
\hline Monotropa uniflora & 0.42 & 0.47 & 0.58 & 0.13 & 0.0016 \\
\hline Oxalis acetosella ssp. montana & 15.40 & 9.61 & 11.79 & 6.01 & 0.0849 \\
\hline \multicolumn{6}{|l|}{ Recalcitrant } \\
\hline Acer spicatum & 25.41 & 29.27 & 27.51 & 21.15 & 0.6159 \\
\hline Corylus cornuta & 5.52 & 5.32 & 5.14 & 6.71 & 0.9206 \\
\hline Populus tremuloides & 0.05 & 0.01 & 0.36 & 0.44 & 0.1056 \\
\hline Prunus pensylvanica & 0.04 & 0.29 & 2.24 & 3.56 & 0.0441 \\
\hline Pteridium aquilinum & 1.25 & 1.20 & 0.40 & 0.42 & 0.6335 \\
\hline Rubus idaeus & 0.41 & 0.44 & 3.52 & 2.83 & 0.0370 \\
\hline
\end{tabular}

Mean relative occurrence values (\%) are presented and two-way permutation ANOVA p-values. Significant treatment effects are represented by a $P$-value in bold $(P<0.05)$. Within rows, means followed by the same letter do not differ significantly from one another at $a=0.05$ according to pairwise Tukey's tests. CON: controls; SIN: single-tree selection cut; GRP: group-selection cut; GRPS: group-selection cut with scarification.

\section{Effects of silvicultural treatments on beta diversity of plant communities}

Silvicultural treatments explained less variation in the understorey plant species assemblage and biological types than did the site location (Table 3). The interaction between regeneration treatments and sites was also significant. Based on the two-way comparison of treatments, species assemblage $(P=$ 
0.048) and biological type assemblage $(P=0.024)$ in the control forests differed from those in the GRPS (Table 4). Silvicultural treatments did not significantly affect beta diversity between silvicultural treatments $(P=0.10)$. Nevertheless, beta diversity between silvicultural treatments in CON and SIN tended to be higher than in GRP and GRPS (Fig. 4). Silvicultural treatments had a significant effect on beta diversity between sites $(P=0.018)$. Beta diversity between sites in CON and SIN was higher than in GRPS (Fig. 4).

Legend: Beta diversity among sites as a function of treatments ( $\left.B_{\text {between_Sites }}\right)$ are plotted as mean Euclidean distances between centroids for the same treatments and $(b)$ beta diversity among regeneration treatments $\left(B_{\text {between_Treat }}\right)$ are plotted as Euclidean distances to the centoid as a function of the regeneration treatments. CON: controls; SIN: single-tree selection cut; GRP: group-selection cut; GRPS: group-selection cut with scarification.

\section{Discussion}

\section{Effects of silvicultural treatments on soil properties}

First of all, the silvicultural treatments considered in our study had more limited longer term effects on soil properties than we had anticipated although other studies have shown medium-term recovery of soil chemical properties following forest harvesting and scarification treatments (Hope 2007). However, in our high intensity treatment (GRPS), substantial decrease in FH-horizon thickness, $\mathrm{C} / \mathrm{N}$ ratio and exchangeable $\mathrm{K}$ were still observed 20 years after treatment compared to control forests. This decrease can be attributed to the extraction of forest biomass and subsequently lower inputs of fresh litter (SaintLaurent et al. 2000; Thiffault et al. 2011; Clarke et al. 2015), higher litter decomposition rates from early successional species (i.e., with lower $\mathrm{C} / \mathrm{N}$ ratios) compared to late-stage species (Kazakou et al. 2009), and the burial of surface organic matter in the soil mineral horizon (Henneb et al. 2019). In addition, an increase in light availability and soil temperature in the short- term following GRPS can enhance rates of decomposition and C-mineralization in the soil organic horizon (Nieminen 2004; Bekele et al. 2007; Diochon et al. 2009). Our results indicate that high-intensity silvicultural treatments in temperate hardwood forests can leave a legacy effect on soils that persists in the medium-term, especially in the surface horizon. Other studies suggest that it may take several decades for soil properties to recover from the effects of high-intensity silvicultural treatments (Prest et al. 2014; Zhou et al. 2015; Bowd et al. 2019).

However, we found site location to explain more of the variation in soil properties than did silvicultural treatments, which has been observed in other studies (e.g., Heuvelink and Webster 2001; Nave et al.

2010). Indeed, soil properties are largely influenced by natural inter-site variability in surface deposits, and biotic and abiotic conditions that are associated with regional and local variation in climate and microclimate, together with vegetation type, and the phenological and phenotypic characteristics of the most abundant species (Walmsley et al. 2009; Jang et al. 2016). 


\section{Relationships between soil properties and understorey plant communities}

Our results show that much of the variability in understory plant community composition is associated with variation in soil properties between sites. For example, we observed that sites with a more coniferous understory were associated with higher $\mathrm{C} / \mathrm{N}$ ratios in the organic horizon and lower $\mathrm{pH}$ values in the organic and mineral horizons. Lower pH can limit activity of the soil microflora and fauna, leading to lower rates of litter decomposition, thereby resulting in increased organic soil accumulation and $\mathrm{C} / \mathrm{N}$ ratios (Sinsabaugh et al. 2008). Such changes in edaphic conditions and the presence of feedback processes between soil nutrients and the above- and belowground parts of decomposing plants can markedly alter the plant composition of the understory (Hobbie 2015; Zhang et al. 2016). Indeed, understory plant communities are very sensitive to the nature of surface deposits, texture, horizon thickness, pH, and nutrient availability (Haeussler et al. 2002; Vockenhuber et al. 2011).

Furthermore, different taxonomic groups respond differently to edaphic changes that result from silvicultural treatments (Paillet et al. 2010). For example, the shrub and grass groups are associated with lower $\mathrm{C} / \mathrm{N}$ ratios and thinner organic horizons in intensively disturbed forests, whereas the sporophyte group and some forbs (e.g., genus Pyrola, Goldthread [Coptis trifolia]) were mainly found in control forests with a thicker FH-horizon. These species are known to favour stable edaphic conditions and a dense cover of mature trees with increased litterfall in the autumn (Vockenhuber et al. 2011; Márialigeti et al. 2016).

\section{Effects of silvicultural treatments on understory plant community composition}

Species richness of understory plant communities in the more intense treatments (i.e., GRP and GRPS) was slightly, but significantly, higher than in the control forests. The increase in the intensity of soil and canopy disturbance would have led to an increase in resource availability (e.g. light, nutrients), especially for early successional species (Keenan and Kimmins 1993; Wardle et al. 2003), which may have favoured the presence of a greater number of species (Deconchat and Balent 2001; Hilmers et al. 2018). At the same time, species richness and composition in the SIN were similar to those in the CON forests. These results accord with other studies that have measured negligible effects of single-tree section cuts on both environmental conditions and understory plant diversity (Smith et al. 2008; Raymond et al. 2018).

The species equitability index in the GRPSs was lower than in the CON and SIN forests, indicating dominance of certain species in the GRPSs. Soil scarification treatments are frequently given little consideration from a biodiversity conservation perspective (Duguid et al. 2013), particularly in the boreal forest where the combination of high soil and canopy disturbance can have negative effects on the abundance of species that are known to be sensitive to habitat change (e.g., epiphytic bryophytes, lichens) (Bergstedt et al. 2008; Caners et al. 2013; Venier et al. 2015). Open and disturbed environments mainly favour pioneer species (Clavel et al. 2011; Tullus et al. 2018), which benefit from an ability to 
initiate efficient differential physiological responses through a wide range of functional trait values (Violle et al. 2007; Mayfield et al. 2010). Thus, we observed higher relative occurrence values in GRP and GRPS for early successional species, but also identified the latter as being recalcitrant from the literature (e.g., Rubus spp, pin cherry (Prunus pensy/vanica)) (Jobidon 1995; Royo and Carson 2006), 20 years after the most intensive silvicultural treatments, compared to control forests and SINs. Furthermore, although the dominance of pioneer species following the intensification of forest disturbances is likely to disappear over time (Bergeron et al. 2014; Yeboah et al. 2016), it is known that soil disturbances generated by scarification or forest harvesting activities can lead to species dominance effects and a time lag in the recovery and recolonisation processes of species adapted to natural forests (Bergstedt et al. 2008). Finally, although the presence of shade-intolerant and competitive pioneer species is not at the expense of late-successional species requiring more stable environmental conditions, severe soil disturbance may constrain dispersal and recruitment processes for the regeneration of forest interior species, thereby favouring the longer-term persistence of competitive and vegetatively reproducing pioneer species through interspecific competition and exclusion processes (Aschehoug et al. 2016).

\section{Effects of silvicultural treatments on the beta diversity of understory plant communities}

The combination of edaphic and microclimatic conditions within a bioclimatic region that undergoes the natural disturbance regime would generate a region-specific assemblage of indicator species. This assemblage is involved in maintaining beta diversity between geographically distant sites at the landscape scale (Vellend 2010; Saucier et al. 2010). Although control forests and SINs in our study had fewer understory species on average, they were associated with higher beta diversity between sites compared to GRPS, indicating more heterogeneous plant communities across forests and sites. Several studies have attributed similar results to increased resource heterogeneity and understory structural diversity in unevenly managed and control forests (i.e., SINs) compared to the most disturbed forests, which may favour the development of biotic homogenization processes (Falk et al. 2008; Brewer et al. 2012; Markgraf et al. 2020). However, other studies have shown limitations to uneven-aged management that initiates only small disturbances, including lack of early successional habitats and landscape-scale homogenisation of stand structure and composition (Werner and Raffa 2000; Decocq et al. 2004; Angers et al. 2005). Furthermore, heavy canopy and soil disturbances, although less frequent in the natural disturbance regime within temperate hardwood forests (Runkle 1985), may allow specific regeneration needs to be met and favour the presence of pioneer plant species important for biodiversity (Swanson et al. 2011).

Finally, plant communities are sensitive to intense silvicultural disturbance and ecosystem-based management that is characterized by a low-level intensity of canopy and soil disturbance (Schall et al. 2017). In both cases, biotic homogenization can occur at the landscape scale and steer ecological successional processes towards either predominantly juvenile or old growth communities (Angers et al. 2005; Kern et al. 2017; Schall et al. 2017). In this sense, silvicultural management needs to find a balance 
at the landscape scale that allows for both light and moderate disturbances while drawing on natural dynamics.

\section{Conclusions}

Our results suggest that, in temperate hardwood forests, there is a legacy of high-intensity silvicultural treatments on soil properties, particularly in the surface horizon. This legacy, in turn, can affect the composition and diversity of understory plant communities. The most intense silvicultural treatments (i.e., GRP and GRPS) not only resulted in slight increased species richness in the medium-term, but also a decrease in understory plant community heterogeneity. The most intense silvicultural treatments resulted in an increased relative occurrence of shade-intolerant, mainly vegetatively reproducing species adaptated to disturbed environments. These treatments contributed to the persistence of competitive potentially recalcitrant species which coud compete with commercial species and and alter plant community composition. Among the studied treatments, single-tree selection cutting (SIN) appeared to be the most appropriate silvicultural treatment for maintaining soil functions and understory plant communities of unmanaged forests. On the other side, more intense treatments favored species adapted to a wider range of environmental conditions, including open environments. Therefore, at the landscape level, the guarantee of maintaining the highest biodiversity of plant communities will lie in the search for adequate spatial representativeness of the different silvicultural treatments by considering the functions of the species that they favor over the long term.

\section{Abbreviations}

Al: Aluminium; $\mathrm{B}_{\text {between_Site: }}$ Beta diversity between sites; $\mathrm{B}_{\text {between_Treat }}$ : Beta diversity between treatments; C: Carbon; $\mathrm{Ca}$; Calcium; $\mathrm{C} / \mathrm{N}$ : Carbon/Nitrate ratio; $\mathrm{CON}$ : Control forests with no silvicultural treatments for at least 80 years; CWM: Community weighted mean; $\mathrm{d}_{\text {cen }}$ : Distance to the centroid; E: Evenness; $\mathrm{F}$ :

Relative occurrence; Fdis: Functionnal dispersion; FH: Fibro-humic horizon; GRP: Group-selection cutting; GRPS: Group-selection cutting with scarification; H': Shannon index; K: Potassium; N: Nitrate; P:

Phosphore; S: Species richness; SIN: Single-tree selection cutting.

\section{Declarations}

\section{Acknowledgments}

We would like to thank Hélène Lalande and Eve-Marie Hébert for their technical assistance. Thanks to the Canadian Trait Network and Laura Boisvert-Marsh to make the functional trait data available. Dr. William F.J. Parsons revised the English.

\section{Funding}

This research was made possible through the financial support of MFFP (Ministère de la faune, des forêts et des parcs du Québec). 
Availability of data and materials

Data are available from the corresponding author on request.

\section{Ethics approval and consent to participate}

The subject has no ethic risk.

\section{Consent for publication}

Not applicable.

\section{Competing interests}

The authors declare no conflict of interest. The funders had no role in the design of the study; in the collection, analyses, or interpretation of data; in the writing of the manuscript, or in the decision to publish the results.

\section{Authors' contributions}

R.J, S.D. and D.R. developed the idea; R.J. collected and analyzed the data, and wrote the first draft of the manuscript; S.D., I.A., G.J., P.R. and D.R. contributed critically to the drafts and approved the final manuscript.

\section{References}

1. Anderson MJ (2017) Permutational Multivariate Analysis of Variance (PERMANOVA). Statistics Reference Online, Wiley StatsRef

2. Anderson MJ, Crist TO, Chase JM, Vellend M, Inouye BD, Freestone AL, Inouye BD, Freestone AL, Sanders NJ, Cornell HV, Comita LS, Davies KF, Harrison SP, Kraft NJB, Stegen JC, Swenson NG (2011) Navigating the multiple meanings of $\beta$ diversity: a roadmap for the practicing ecologist. Ecol Let 14(1):19-28. https://doi.org/10.1111/j.1461-0248.2010.01552.x

3. Angers AA, Messier C, Beaudet M, Leduc A (2005) Comparing composition and structure in oldgrowth and harvested (selection and diameter-limit cuts) northern hardwood stands in Quebec. For Ecol Manag 217:275-293. https://doi.org/10.1016/j.foreco.2005.06.008

4. Archambault L, Morissette JL, Bernier-Cardou M (1998) Forest succession over a 20-year period following clearcutting in balsam fir-yellow birch ecosystems of eastern Quebec, Canada. For Ecol Manage 102:61-74. https://doi.org/10.1016/S0378-1127(97)00109-6

5. Aschehoug ET, Brooker R, Atwater DZ, Maron JL, Callaway RM (2016) The mechanisms and consequences of interspecific competition among plants. Annu Rev Ecol Evol Syst 47(1):263-281. https://doi.org/10.1146/annurev-ecolsys-121415-032123 
6. Aubin I, Gachet S, Messier C, Bouchard A (2007) How resilient are northern hardwood forests to human disturbance? An evaluation using a plant functional group approach. Ecoscience 14(2):259271. https://doi.org/10.2980/1195-6860(2007)14[259:hranhf]2.0.co;2

7. Aubin I, Cardou F, Boisvert-Marsh L, Strukelj M, Munson A (2020) Managing data locally to answer global-scale questions in ecology: the role of collaborative science. J Veg Sci 31(3):509-517. https://doi.org/10.1111/jvs.12864

8. Aussenac G (2000) Interactions between forest stands and microclimate: Ecophysiological aspects and consequences for silviculture. Ann For Sci 57(3):287-301. https://doi.org/10.1051/forest:2000119

9. Azeria ET, Ibarzabal J, Hébert C (2012) Effects of habitat characteristics and interspecific interactions on co-occurrence patterns of saproxylic beetles breeding in tree boles after forest fire: null model analyses. Oecologia 168:1123-1135. https://doi.org/10.1007/s00442-011-2180-0

10. Baselga A (2010) Partitioning the turnover and nestedness components of beta diversity. Glob Ecol Biogeogr 19:134-143. https://doi.org/10.1111/j.1466-8238.2009.00490.x

11. Baselga A (2012) The relationship between species replacement, dissimilarity derived from nestedness, and nestedness. Glob Ecol Biogeogr 21:1223-1232. https://doi.org/10.1111/j.14668238.2011.00756.x

12. Bekele A, Kellman L, Beltrami $\mathrm{H}$ (2007) Soil profile $\mathrm{CO}_{2}$ concentrations in forested and clear cut sites in Nova Scotia, Canada. For Ecol Manage 242(2):587-597. https://doi.org/10.1016/j.foreco.2007.01.088

13. Bergeron Y, Chen HYH, Kenkel NC, Leduc AL, Macdonald SE (2014) Boreal mixedwood stand dynamics: Ecological processes underlying multiple pathways. For Chron 90(02):202-213. https://doi.org/10.5558/tfc2014-039

14. Bergstedt J, Hagner M, Milberg P (2008) Effects on vegetation composition of a modified forest harvesting and propagation method compared with clear-cutting, scarification and planting. Appl Veg Sci 11(2):159-168. https://doi.org/10.3170/2007-7-18343

15. Borcard D, Gillet F, Legendre P (2011) Numerical Ecology with R. Springer, New York

16. Bowd EJ, Banks SC, Strong CL, Lindenmayer DB (2019) Long-term impacts of wildfire and logging on forest soils. Nat Geosci 12:113-118

17. Brewer J, Bertz C, Cannon J, Chesser J, Maynard E (2012) Do natural disturbances or the forestry practices that follow them convert forests to early-successional communities? Ecol Appl 22(2):442458. https://doi.org/10.1890/11-0386.1

18. Brockerhoff EG, Jactel H, Parrotta JA (2008) Plantation forests and biodiversity: oxymoron or opportunity? Biodivers Conserv 17:925-951

19. Brooks ME, Kristensen K, van Benthem KJ, Magnusson A, Berg CW, Nielsen A, Skaug HJ, Maechler M, Bolker BM (2017) glmmTMB balances speed and flexibility among packages for zero-inflated generalized linear mixed modeling. R J 9(2):378-400. https://journal.r-project.org/archive/2017/RJ2017-066/index.html 
20. Cadotte MW, Carscadden K, Mirotchnick N (2011) Beyond species: functional diversity and the maintenance of ecological processes and services. J Appl Ecol 48(5):1079-1087. https://doi.org/10.1111/j.1365-2664.2011.02048.x

21. Caners RT, Macdonald SE, Belland RJ (2013) Bryophyte assemblage structure after partial harvesting in boreal mixedwood forest depends on residual canopy abundance and composition. For Ecol Manage 289:489-500. https://doi.org/10.1016/j.foreco.2012.09.044

22. Chaudhary A, Burivalova Z, Koh LP, Hellweg S (2016) Impact of forest management on species richness: global meta-analysis and economic trade-offs. Sci Rep 6(1):23954. https://doi.org/10.1038/srep23954

23. Clarke N, Gundersen P, Jönsson-Belyazid U, Kjønaas OJ, Persson T, Sigurdsson BD, Stupak I, Vesterdal L (2015) Influence of different tree-harvesting intensities on forest soil carbon stocks in boreal and northern temperate forest ecosystems. For Ecol Manag 351:9-19. https://doi.org/10.1016/j.foreco.2015.04.034

24. Clavel J, Julliard R, Devictor V (2011) Worldwide decline of specialist species: toward a global functional homogenization? Front Ecol Environ 9(4):222-228. https://doi.org/10.1890/080216

25. Daly AJ, Baetens JM, De Baets B (2018) Ecological diversity: Measuring the unmeasurable. Mathematics 6(7):119. https://doi.org/10.3390/math6070119

26. D'Amato AW, Jokela EJ, O'Hara KL, Long JN (2018) Silviculture in the United States: An amazing period of change over the past 30 years. J For 116(1):55-67. https://doi.org/10.5849/JOF-2016-035

27. Decocq G, Aubert M, Dupont F, Alard D, Saguez R, Wattez-Franger A, De Foucault B, Delelis-Dusollier A, Bardat J (2004) Plant diversity in a managed temperate deciduous forest: understorey response to two silvicultural systems. J Appl Ecol 41:1065-1079. https://doi.org/10.1111/j.00218901.2004.00960.x

28. Deconchat M, Balent G (2001) Vegetation and bird community dynamics in fragmented coppice forests. Forestry 74(2):105-118. https://doi.org/10.1093/forestry/74.2.105

29. Diochon A, Kellman L, Beltrami H (2009) Looking deeper: an investigation of soil carbon losses following harvesting from a managed northeastern red spruce (Picea rubens Sarg.) forest chronosequence. For Ecol Manage 257(2):413-420. https://doi.org/10.1016/j.foreco.2008.09.015

30. Duguid MC, Ashton MS (2013) A meta-analysis of the effect of forest management for timber on understory plant species diversity in temperate forests. For Ecol Manage 303:81-90. https://doi.org/10.1016/j.foreco.2013.04.009

31. Duguid MC, Frey BR, Ellum DS, Kelty M, Ashton MS (2013) The influence of ground disturbance and gap position on understory plant diversity in upland forests of southern New England. For Ecol Manage 303:148-159. https://doi.org/10.1016/j.foreco.2013.04.018

32. Elliott KJ, Knoepp JD (2005) The effects of three regeneration harvest methods on plant diversity and soil characteristics in the southern Appalachians. For Ecol Manage 211(3):296-317. https://doi.org/10.1016/j.foreco.2005.02.064 
33. Ellum DS (2009) Floristic diversity in managed forests: demography and physiology of understory plants following disturbance in southern New England forests. J Sustain For 28(1-2):132-151. https://doi.org/10.1080/10549810802626431

34. Erdmann GG (1990) Yellow birch. Betula alleghaniensis Britton. In Burns RM Honkala BH (techcoords), Silvics of North America: Volume 2. Hardwoods. USDA For. Serv., Washington, DC, USA pg. 877

35. Falk KJ, Burke DM, Elliott KA, Holmes SB (2008) Effects of single-tree and group selection harvesting on the diversity and abundance of spring forest herbs in deciduous forests in southwestern Ontario. For Ecol Manage 255(7):2486-2494. https://doi.org/10.1016/j.foreco.2008.01.033

36. Flinn KW (2007) Microsite-limited recruitment controls fern colonization of post-agricultural fields. Ecology 88:3103-3114. https://doi.org/10.1890/06-2124.1

37. Foley JA, Defries R, Asner GP, Barford C, Bonan G, Carpenter SR, Chapin III, Coe FS, Daily MT, Gibbs GR, Helkowski HK, Holloway JH, Howard T, Kucharik EA, Monfreda CJ, Patz C, Prentice JA, Ramankutty IC, Snyder N PR (2005) Global consequences of land use. Science 309:570. https://doi.org/10.1126/science.1111772

38. Gauthier M-M, Lambert M-C, Bédard S (2016) Effects of harvest gap size, soil scarification, and vegetation control on regeneration dynamics in sugar maple-yellow birch stands. For Sci 62(2):237246. https://doi.org/10.5849/forsci.15-058

39. Gilliam FS, Roberts MR (1995) Impacts of forest management on plant diversity. Ecol Appl 5(4):911912. https://doi.org/10.1371/journal.pone.0233292

40. Gracia M, Montané F, Piqué J, Retana J (2007) Overstory structure and topographic gradients determining diversity and abundance of understory shrub species in temperate forests in central Pyrenees (NE Spain). For Ecol Manage 242(2):391-397. https://doi.org/10.1016/j.foreco.2007.01.056

41. Haeussler S, Bedford L, Leduc A, Bergeron Y, Kranabetter JM (2002) Silvicultural disturbance severity and plant communities of the southern Canadian boreal forest. Silva Fenn 36(1):307-327. https://doi.org/10.14214/sf.565

42. Hart JL, Grissino-Mayer HD (2009) Gap-scale disturbance processes in secondary hardwood stands on the Cumberland Plateau, Tennessee, USA. Plant Ecol 201:131-146. https://doi.org/ 10.1007/97890-481-2795-5\$411

43. Hendershot $W H$, Lalande $H$, Duquette $M(2008)$ Soil reaction and exchangeable acidity. In: Carter MR, Gregorich MR (eds) Soil Sampling and Methods of Analysis, 2nd edn. CRC, Boca Raton, pp 173-178

44. Henneb M, Valeria O, Thiffault N, Fenton NJ, Bergeron Y (2019) Effects of mechanical site preparation on microsite availability and growth of planted black spruce in Canadian paludified forests. Forests 10(8):670. https://doi.org/10.3390/f10080670

45. Heuvelink GBM, Webster R (2001) Modelling soil variation: past, present. and future Geoderma 100(3-4):269-301. https://doi.org/10.1016/S0016-7061(01)00025-8 
46. Hilmers T, Friess N, Bässler C, Heurich M, Brandl R, Pretzsch H, Seidl R, Müller J (2018) Biodiversity along temperate forest succession. J Appl Ecol 55(6):2756-2766. https://doi.org/10.1111/13652664.13238

47. Hobbie SE (2015) Plant species effects on nutrient cycling: revisiting litter feedbacks. Trends Ecol Evol 30(6):357-363. https://doi.org/10.1016/j.tree.2015.03.015

48. Hooper DU, Chapin FS III, Ewel JJ, Hector A, Inchausti P, Lavorel S, Lawton JH, Lodge DM, Loreau M, Naeem S, Schmid B, Setälä H, Symstad AJ, Vandermeer J, Wardle DA (2005) Effects of biodiversity on ecosystem functioning: a consensus of current knowledge. Ecol Monogr 75(1):3-35. https://doi.org/10.1890/04-0922

49. Hope GD (2007) Changes in soil properties, tree growth, and nutrition over a period of 10 years after stump removal and scarification on moderately coarse soils in interior British Columbia. For Ecol Manage 242(2-3):625-635. https://doi.org/10.1016/j.foreco.2007.01.072

50. Hothorn T, Bretz F, Westfall P (2008) Simultaneous inference in general parametric models. Biom J 50(3):346-363. https://doi.org/10.1002/bimj.200810425

51. Jang W, Page-Dumroese DS, Keyes CR (2016) Long-term soil changes from forest harvesting and residue management in the northern Rocky Mountains. Soil Sci Soc Am J 80(3):727-741. https://doi.org/10.2136/sssaj2015.11.0413

52. Jobidon R (1995) Autécologie de quelques espèces de compétition d'importance pour la régénération forestière au Québec. Mémoire de recherche forestière n¹17. Gouvernement du Québec. Direction de la recherche forestière

53. Jost L (2006) Entropy and diversity. Oikos 113:363-375. https://doi.org/10.1111/j.2006.00301299.14714.x

54. Kazakou E, Violle C, Roumet C, Pintor C, Gimenez O, Garnier E (2009) Litter quality and decomposability of species from a Mediterranean succession depend on leaf traits but not on nitrogen supply. Ann Bot 104(6):1151-1161. https://doi.org/10.1093/aob/mcp202

55. Keenan RJ, Kimmins JP (1993) The ecological effects of clear-cutting. Environ Rev 1(2):121-144. Retrieved June 22, 2021, from http://www.jstor.org/stable/envirevi.1.2.121

56. Kern CC, Burton JI, Raymond P, D'Amato AW, Keeton WS, Royo AA, Walters MB, Webster CR, Willis JL (2017) Challenges facing gap-based silviculture and possible solutions for mesic northern forests in North America. Forestry 90(1):4-17. https://doi.org/10.1093/forestry/cpw024

57. Laliberté E, Legendre P (2010) A distance-based framework for measuring functional diversity from multiple traits. Ecology 91:299-305. https://doi.org/10.1890/08-2244.1

58. Lavorel S, Díaz S, Cornelissen JHC, Garnier E, Harrison SP, McIntyre S, Pausas JG, PérezHarguindeguy N, Roumet C, Urcelay C (2007) Plant Functional Types: Are We Getting Any Closer to the Holy Grail? Global Change - The IGBP Series, 149-164. https://doi.org/10.1007/978-3-54032730-1_13

59. Legendre P, Mi X, Ren H, Ma K, Yu M, Sun I-F, He F (2009) Partitioning beta diversity in a subtropical broad-leaved forest of China. Ecology 90(3):663-674. https://doi.org/10.1890/07-1880.1 
60. Lindenmayer DB, Franklin JF, Lõhmus A, Baker SC, Bauhus J, Beese W et al (2012) A major shift to the retention approach for forestry can help resolve some global forest sustainability issues: retention forestry for sustainable forests. Conserv Lett 5:421-431. https://doi.org/10.1111/j.1755263X.2012.00257.x

61. Lindenmayer D, Messier C, Sato C (2016) Avoiding ecosystem collapse in managed forest ecosystems, Frontiers in Ecology and the Environment, vol. 14, no. 10, pp. 561-568

62. Markgraf R, Doyon F, Kneeshaw D (2020) Forest landscape heterogeneity increases shrub diversity at the expense of tree seedling diversity in temperate mixedwood forests. Forests 11(2):160. https://doi.org/10.3390/f11020160

63. Márialigeti S, Tinya F, Bidló A, Ódor P (2016) Environmental drivers of the composition and diversity of the herb layer in mixed temperate forests in Hungary. Plant Ecol 217(5):549-563. https://doi.org/10.1007/s11258-016-0599-4

64. Marie-Victorin Fr, Rouleau E, Brouillet L (2002) Flore Laurentienne [Laurentian Flora, in French], 3rd edition, Éditions Gaëtan Morin. Montreal. 1112 pages

65. Mayfield MM, Bonser SP, Morgan JW, Aubin I, McNamara S, Vesk PA (2010) What does species richness tell us about functional trait diversity? Predictions and evidence for responses of species and functional trait diversity to land-use change. Glob Ecol Biogeogr 19(4):423-431. https://doi.org/10.1111/j.1466-8238.2010.00532.x

66. Messier C, Bauhus J, Doyon F, Maure F, Sousa-Silva R, Nolet P, Mina M, Aquilué N, Fortin M-J, Puettmann K (2019) The functional complex network approach to foster forest resilience to global changes. For Ecosyst 6(1):21. https://doi.org/10.1186/s40663-019-0166-2

67. Moisan-De Serres A, Gélinas N, Marcotte P (2018) Les produits forestiers non ligneux: une opportunité de développement touristique régional. J Rural Community Dev 12(2-3):168-185

68. Moola FM, Vasseur L (2008) The maintenance of understory residual flora with even-aged forest management: a review of temperate forests in northeastern North America. Environ Rev 16:141-155. https://doi.org/10.1139/A08-005

69. Naaf T, Wulf M (2007) Effects of gap size, light and herbivory on the herb layer vegetation in European beech forest gaps. For Ecol Manage 244(1-3):141-149.

https://doi.org/10.1016/j.foreco.2007.04.020

70. Nave E, Vance ED, Swanston CW, Curtis PS (2010) Harvest impacts on soil carbon storage in temperate forests. For Ecol Manage 259(5):857-866. https://doi.org/10.1016/j.foreco.2009.12.009

71. Nieminen M (2004) Export of dissolved organic carbon, nitrogen and phosphorus following clearcutting of three Norway spruce forests growing on drained peatlands in southern Finland. Silva Fenn 38(2). https://doi.org/10.14214/sf.422

72. Nolet P, Kneeshaw D, Messier C, Béland M (2018) Comparing the effects of even- and uneven-aged silviculture on ecological diversity and processes: a review. Ecol Evol 8(2):1217-1226.

https://doi.org/10.1002/ece3.3737 
73. O'Hara KL (2015) What is close-to-nature silviculture in a changing world? Forestry 89:1-6. https://doi.org/10.1093/forestry/cpv043

74. Oksanen J, Blanchet FG, Friendly M, Kindt R, Legendre P, McGlin D, Minchin P, O'Hara RB, Simpson GL, Solymos P, Stevens MHH, Wagner H (2017) vegan: Community Ecology Package. R package Version 2.4-3

75. Paillet Y, Bergès L, Hjältén J, Ódor P, Avon C, Bernhardt-Römermann M, Bijlsma R-J, De Bruyn L, Fuhr M, Grandin U, Kanka R, Lundin L, Luque S, Magura T, Matesanz S, Mészáros I, Sebastià M-T, Schmidt W, Standovár T, Virtanen R (2010) Biodiversity differences between managed and unmanaged forests: meta-analysis of species richness in Europe. Conserv Biol 24(1):101-112. https://doi.org/10.1111/j.1523-1739.2009.01399.x

76. Paquette A, Messier C (2010) The role of plantations in managing the world's forests in the Anthropocene. Front Ecol Environ 8(1):27-34. https://doi.org/10.1890/080116

77. Peres-Neto PR, Legendre P, Dray S, Borcard D (2006) Variation partitioning of species data matrices: Estimation and comparison of fractions. Ecology 87(10):2614-2652. https://doi.org/10.1890/00129658(2006)87[2614:VPOSDM]2.0.C0;2

78. Powers MD, Nagel LM (2009) Pennsylvania sedge cover, forest management and deer density influence tree regeneration dynamics in a northern hardwood forest. Forestry 82(3):241-254. https://doi.org/10.1093/forestry/cpp003

79. Poznanovic SK, Webster CR, Bump JK (2013) Maintaining mid-tolerant tree species with unevenaged forest management: 9-year results from a novel group-selection experiment. Forestry 86(5):555-567. https://doi.org/10.1093/forestry/cpt025

80. Prest D, Kellman L, Lavigne MB (2014) Mineral soil carbon and nitrogen still low three decades following clearcut harvesting in a typical Acadian forest stand. Geoderma 214-215:62-69. https://doi.org/10.1016/j.geoderma.2013.10.002

81. Puettmann KJ, Coates KD, Messier C (2009) A Critique of Silviculture: Managing for Complexity. Island Press, Washington, DC, 206 pp

82. R Core Team (2017) R: A Language and Environment for Statistical Computing

83. https://www.R-project.org/

84. Rao CR (1982) Diversity and dissimilarity coefficients a unified approach. Theor Popul Biol 21:2443. https://doi.org/10.1016/0040-5809(82)90004-1

85. Raymond P, Royo AA, Prévost M, Dumais D (2018) Assessing the single-tree and small group selection cutting system as intermediate disturbance to promote regeneration and diversity in temperate mixedwood stands. For Ecol Manage 430:21-32. https://doi.org/10.1016/j.foreco.2018.07.054

86. Roberts MR (2004) Response of the herbaceous layer to natural disturbance in North American forests. Canadian J Bot 82(9):1273-1283. https://doi.org/10.1139/b04-091

87. Roberts MR, Zhu L (2002) Early response of the herbaceous layer to harvesting in a mixed coniferous-deciduous forest in New Brunswick, Canada. For Ecol Manage 155(1-3):17-31. 
https://doi.org/10.1016/S0378-1127(01)00544-8

88. Rogers NS, Kenefic LS, Crandall MS, Seymour RS, Sendak PE (2018) Sixty years of silviculture in a northern conifer forest in Maine, USA. For Sci 64(1):102-111. https://doi.org/10.5849/FS-2016-014

89. Roxburgh SH, Shea K, Bastow Wilson J (2004) The intermediate disturbance hypothesis: Patch dynamics and mechanisms of species coexistence. Ecology 85(2):359-371.

https://doi.org/10.1890/03-0266

90. Royer-Tardif S, Paquette A, Messier C, Bournival P, Rivest D (2018) Fast-growing hybrids do not decrease understorey plant diversity compared to naturally regenerated forests and native plantations. Biodivers Conserv 27(3):607-631. https://doi.org/10.1007/s10531-017-1452-3

91. Royo AA, Carson WP (2006) On the formation of dense understory layers in forests worldwide: consequences and implications for forest dynamics, biodiversity, and succession. Can J For Res 36(6):1345-1362. https://doi.org/10.1139/x06-025

92. Runkle JR (1985) Disturbance regimes in temperate forests. In: Pickett STA, White PS (eds) The Ecology of Natural Disturbance and Patch Dynamics. Academic Press, New York, pp 17-33. https://doi.org/10.1016/B978-0-08-050495-7.50007-7

93. Saint-Laurent S, Ouimet R, Tremblay S, Archambault L (2000) Évolution des stocks de carbone organique dans le sol après coupe dans la sapinière à bouleau jaune de l'est du Québec. Can J Soil Sci 80:507-514. https://doi.org/10.4141/S99-083

94. Saucier J-P, Gosselin J, Morneau C, Grondin P (2010) Utilisation de la classification de la végétation dans l'aménagement forestier au Québec. Rev For Fr 62(3-4):428-438. https://doi.org/10.4267/2042/38956

95. Saucier J-P, Robitaille A, Grondin P (2009) Cadre bioclimatique du Québec. pp. 186-205. In: Doucet R, Côté M (Eds.), Manuel de foresterie. Éditions Multi-mondes, Québec

96. Schall P, Gossner MM, Heinrichs S, Fischer M, Boch S, Prati D, Jung K, Baumgartner V, Blaser S, Böhm S, Buscot F, Daniel R, Goldmann K, Kaiser K, Kahl T, Lange M, Müller J, Overmann J, Renner SC, Schulze ED, Sikorski J, Tschapka M, Türke M, Weisser WW, Wernheuer B, Wubet T, Ammer C (2017) The impact of even-aged and unevenaged forest management on regional biodiversity of multiple taxa in European beech forests. J Appl Ecol 55:267-278. https://doi.org/10.1111/1365-2664.12950

97. Schütz J-P, Saniga M, Diaci J, Vrška T (2016) Comparing close-to-nature silviculture with processes in pristine forests: lessons from central Europe. An For Sci 73(4):911-921. https://doi.org/10.1007/s13595-016-0579-9

98. Shannon CE (1948) A mathematical theory of communication. The Bell System Technical Journal 27:379-423. https://doi.org/10.1002/j.1538-7305.1948.tb01338.x. 623-656.

99. Shields JM, Webster CR (2007) Ground-layer response to group selection with legacy-tree retention in a managed northern hardwood forest. Can J For Res 37(10):1797-1807. https://doi.org/10.1139/X07-052

100. Siemion J, Burns DA, Murdoch PS, Germain RH (2011) The relation of harvesting intensity to changes in soil, soil water, and stream chemistry in a northern hardwood forest, Catskill Mountains, 
USA. For Ecol Manage 261(9):1510-1519. https://doi.org/10.1016/j.foreco.2011.01.036

101. Sinsabaugh RL, Lauber CL, Weintraub MN, Ahmed B, Allison SD, Crenshaw C, Contosta AR, Cusack D, Frey S, Gallo ME, Gartner TB, Hobbie SE, Holland K, Keeler BL, Powers JS, Stursova M, TakacsVesbach C, Waldrop MP, Wallenstein MD, Zak DR, Zeglin LH (2008) Stoichiometry of soil enzyme activity at global scale. Ecol Lett 11:1252-1264. https://doi.org/10.1111/j.1461-0248.2008.01245.x

102. Smith KJ, Keeton WS, Twery MJ, Tobi DR (2008) Understory plant responses to uneven-aged forestry alternatives in northern hardwood-conifer forests. Can J For Res 38(6):1303-1318. https://doi.org/10.1139/X07-236

103. Swanson ME, Franklin JF, Beschta RL, Crisafulli CM, Della Sala DA, Hutto RL, Lindenmayer DB, Swanson FJ (2011) The forgotten stage of forest succession: early-successional ecosystems on forest sites. Front Ecol Environ 9:117-125. https://doi.org/10.1890/090157

104. Thiffault E, Hannam KD, Paré D, Titus BD, Hazlett PW, Maynard DG, Brais S (2011) Effects of forest biomass harvesting on soil productivity in boreal and temperate forests-A review. Environ Rev 19:278-309. https://doi.org/10.1139/a11-009

105. Tullus T, Rosenvald R, Leis $M$, Lõhmus $P$ (2018) Impacts of shelterwood logging on forest bryoflora: Distinct assemblages with richness comparable to mature forests. For Ecol Manag 411:67-74. https://doi.org/10.1016/j.foreco.2018.01.008

106. Tuomisto $H$ (2010) A consistent terminology for quantifying species diversity? Yes, it does exist. Oecologia 164(4):853-860. https://doi.org/10.1007/s00442-010-1591-7

107. Vellend M (2010) Conceptual synthesis in community ecology. Q Rev Biol 85(2):183-206. https://doi.org/10.1086/652373

108. Venier LA, Thompson I, Trofymow JA, Malcolm J, Langor D, Fleming R, Aubin I, Sturrock R, Patry C, Outerbridge RO, Holmes SB, Haeussler S, DeGrandpre L, Chen H, Bayne E, Arsenault A (2015) Longterm effects of anthropogenic change on biodiversity of Canadian boreal forests. Environmental Reviews 22(1):457-490. https://doi.org/10.1139/er-2013-0075

109. Violle C, Navas M-L, Vile D, Kazakou E, Fortunel C, Hummel I, Garnier E (2007) Let the concept of trait be functional! Oikos 116(5):882-892. https://doi.org/10.1111/j.0030-1299.2007.15559.x

110. Vockenhuber EA, Scherber C, Langenbruch C, Meißner M, Seidel D, Tscharntke T (2011) Tree diversity and environmental context predict herb species richness and cover in Germany's largest connected deciduous forest. Perspect Plant Ecol Evol Syst 13(2):111-119.

https://doi.org/10.1016/j.ppees.2011.02.004

111. Walmsley JD, Jones DL, Reynolds B, Price MH, Healey JR (2009) Whole tree harvesting can reduce second rotation forest productivity. For Ecol Manag 257(3):1104-1111. https://doi.org/10.1016/j.foreco.2008.11.015

112. Webster CR, Lorimer CG (2005) Minimum opening sizes for canopy recruitment of midtolerant tree species: a retrospective approach. Ecol Appl 15:1245-1262. https://doi.org/10.1890/04-0763

113. Werner SM, Raffa KF (2000) Effects of forest management practices on the diversity of groundoccurring beetles in mixed northern hardwood forests of the Great Lakes Region. For Ecol Manag 
139(1-3):135-155. https://doi.org/10.1016/S0378-1127(99)00341-2

114. Willis DA, Martin DB (2020) Estimating diversity in networked ecological communities. Biostatistics, kxaa015. https://doi.org/10.1093/biostatistics/kxaa015

115. Wyatt JL, Silman MR (2010) Centuries-old logging legacy on spatial and temporal patterns in understory herb communities. For Ecol Manag 260:116-124.

https://doi.org/10.1016/j.foreco.2010.04.010

116. Yeboah D, Chen HYH, Kingston S (2016) Tree species richness decreases while species evenness increases with disturbance frequency in a natural boreal forest landscape. Ecol Evol 6(3):842-850. https://doi.org/10.1002/ece3.1944

117. Zhou X, Zhou Y, Zhou C, Wu Z, Zheng L, Hu X, Chen H, Gan J (2015) Effects of cutting intensity on soil physical and chemical properties in a mixed natural forest in southeastern China. Forests 6(12):4495-4509. https://doi.org/10.3390/f6124383

118. Zidia N, Tran TS (2008) Mehlich III - Extractable elements. In: Carter MR, Gregorich EG (eds) Soil Sampling and Methods of Analysis, 2nd edn. CRC, Boca Raton, pp 81-88

\section{Figures}

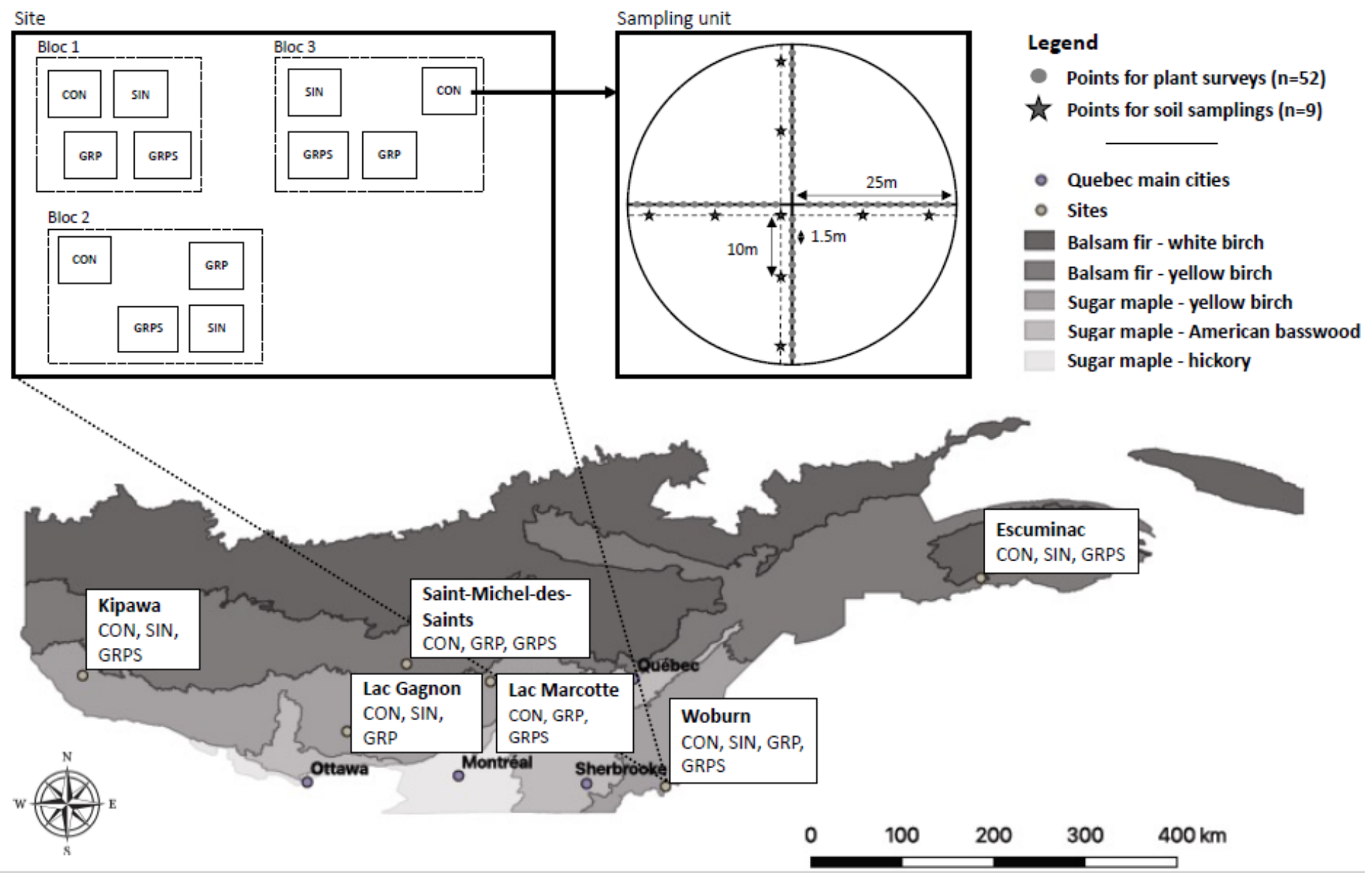

Figure 1 
Geographic location of experimental sites. Information on the bioclimatic domains and silvicultural treatments present in each experimental site. Diagram of the experimental units. Legend: The experimental have a surface area of $1962.5 \mathrm{~m} 2$ comprising 52 floristic inventory points and 9 soil sampling points distributed along the four inventory transects. CON: controls; SIN: single-tree selection cuts; GRP: group-selection cuts; GRPS: group-selection cuts with scarification). Note: The designations employed and the presentation of the material on this map do not imply the expression of any opinion whatsoever on the part of Research Square concerning the legal status of any country, territory, city or area or of its authorities, or concerning the delimitation of its frontiers or boundaries. This map has been provided by the authors.
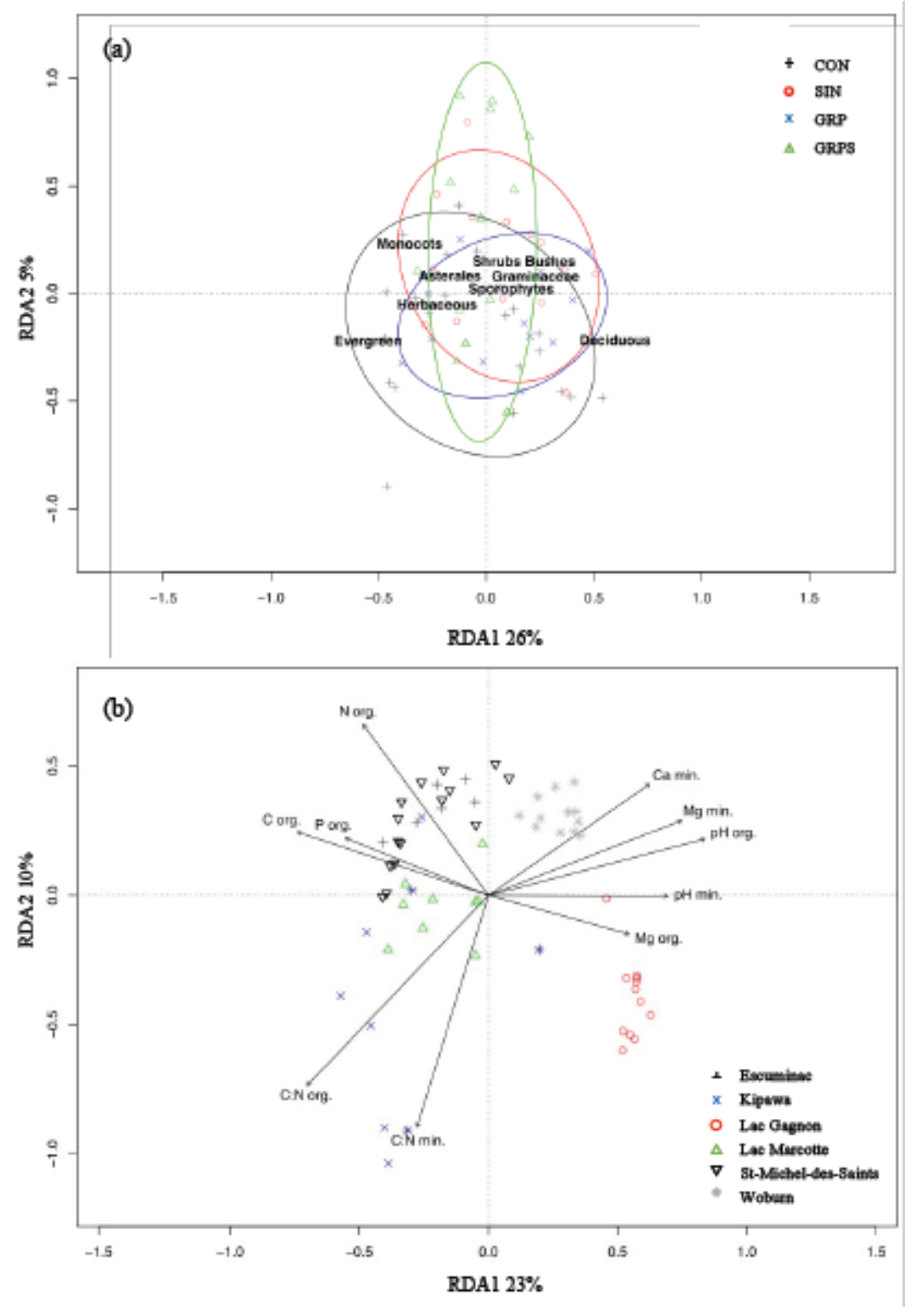

\section{Figure 2}

Tri-plot of redundancy analyses (RDA) showing existing relationships between soil properties, sites, treatments, and understory plant communities. Panel (a) represents taxonomic groups and plots that are grouped by treatments based on soil properties contributing significantly to the model. Panel (b) 
represents the ordination of plots that are grouped by sites based on soil properties contributing significantly to the model. Legend: Sample treatments are indicated by symbols (CON: controls; SIN: single-tree selection cut; GRP: group-selection cut; GRPS: group-selection cut with scarification), explanatory variables by arrows. Percentage variance explained along each axis corresponds to R2.

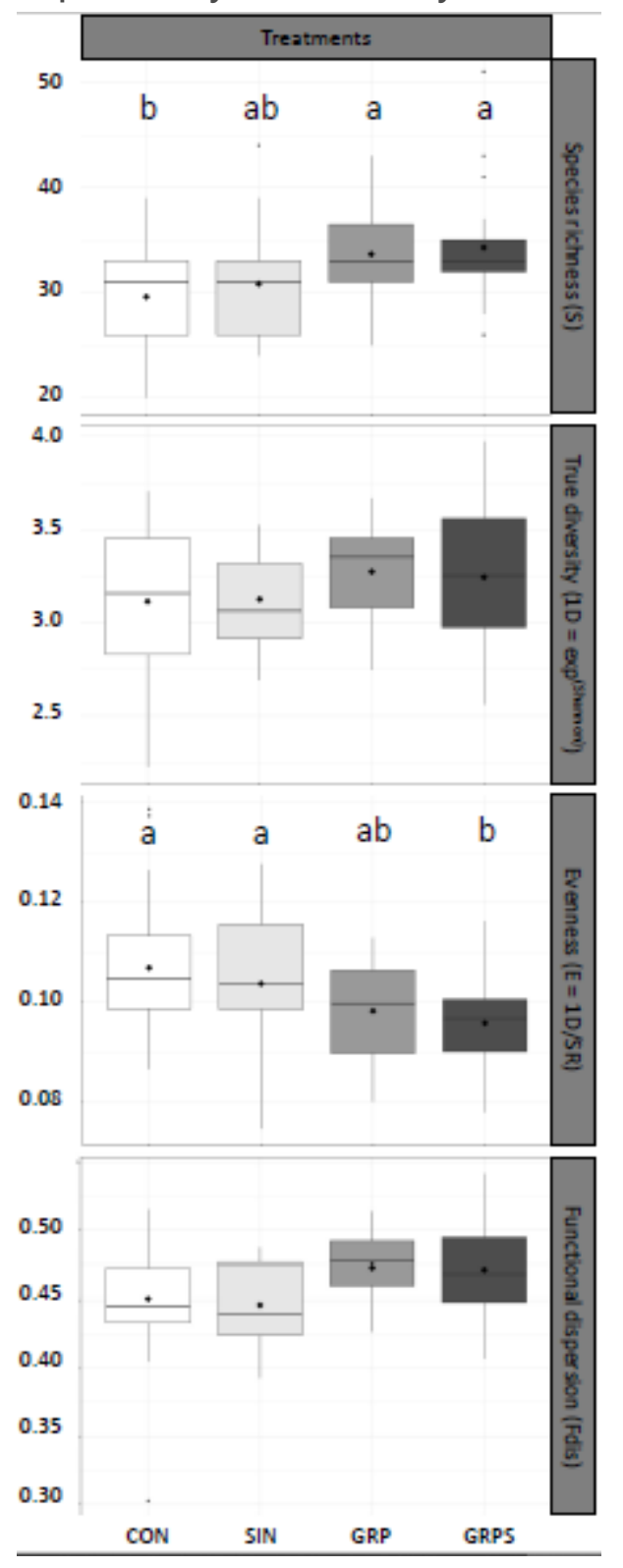

Figure 3

Species richness (S), true diversity (1D), equitability index (E), and functional dispersion index (Fdis) of understory plant communities in southern Quebec, as a function of regeneration treatments. Legend: CON: controls; SIN: single-tree selection cut; GRP: group-selection cut; GRPS: group-selection cut with scarification. Means with different letters significantly differ following pairwise Tukey's tests $(P<0.05)$. Box-and-whisker plots in each panel display 25th and 75th percentiles (the inter-quartile range from the lower and upper edges of the box), the horizontal lines within boxes indicate the 50th percentiles (medians), and bullets within boxes indicate means; whiskers below and above boxes indicate 10th and 90th percentiles, respectively, beyond which dots indicate outliers (values $>1.5 \times$ IQR). 

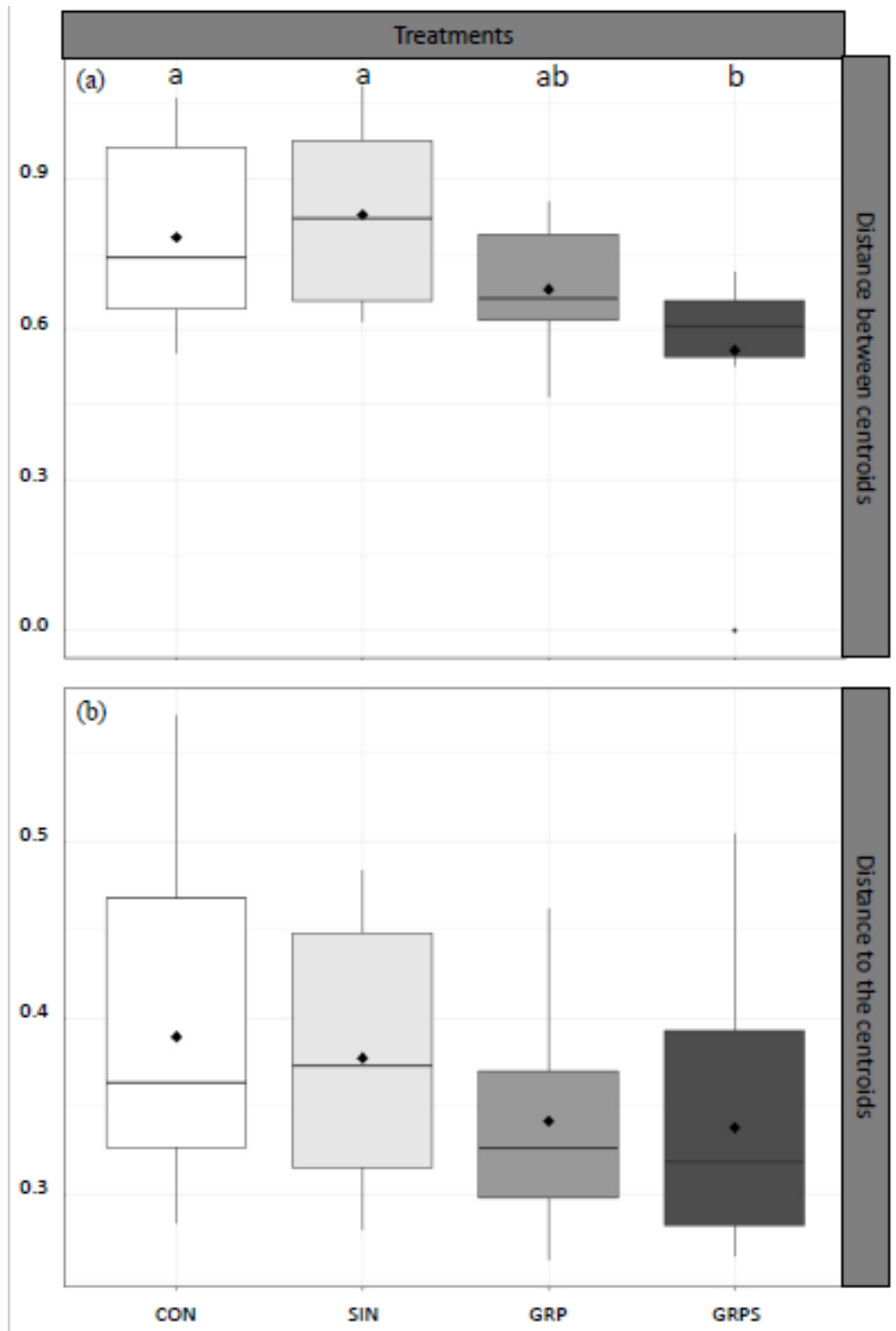

\section{Figure 4}

Multivariate analysis of variance of (a) beta diversity among sites as a function of treatments (Bbetween_Sites) and (b) beta diversity among regeneration treatments (Bbetween_Treat). Legend: Beta diversity among sites as a function of treatments (Bbetween_Sites) are plotted as mean Euclidean distances between centroids for the same treatments and (b) beta diversity among regeneration treatments (Bbetween_Treat) are plotted as Euclidean distances to the centoid as a function of the regeneration treatments. CON: controls; SIN: single-tree selection cut; GRP: group-selection cut; GRPS: group-selection cut with scarification. 